Portland State University

PDXScholar

Civil and Environmental Engineering Master's

Project Reports

Summer 2015

\title{
An Evaluation of the Neighborhood Traffic Management Program of Centennial, Colorado
}

Rolando Gabriel Melgoza

Portland State University

Follow this and additional works at: https://pdxscholar.library.pdx.edu/cengin_gradprojects

Part of the Civil Engineering Commons, and the Transportation Engineering Commons Let us know how access to this document benefits you.

\section{Recommended Citation}

Melgoza, Rolando Gabriel, "An Evaluation of the Neighborhood Traffic Management Program of Centennial, Colorado" (2015). Civil and Environmental Engineering Master's Project Reports. 20. https://doi.org/10.15760/CEEMP.18

This Project is brought to you for free and open access. It has been accepted for inclusion in Civil and Environmental Engineering Master's Project Reports by an authorized administrator of PDXScholar. Please contact us if we can make this document more accessible: pdxscholar@pdx.edu. 


\title{
AN EVALUATION OF THE NEIGHBORHOOD TRAFFIC MANAGEMENT PROGRAM OF
} CENTENNIAL, COLORADO

\section{BY}

\section{ROLANDO GABRIEL MELGOZA}

\begin{abstract}
A research project report submitted in partial fulfillment of the requirement for the degree of
\end{abstract}

\section{MASTER OF SCIENCE \\ IN \\ CIVIL AND ENVIRONMENTAL ENGINEERING}

Project Advisor:

Christopher M. Monsere, Ph.D.

Portland State University

(C)2015 


\section{ACKNOWLEDGMENTS}

I would like to thank Dr. Christopher M. Monsere for his guidance, patience, and encouragement throughout my graduate school experience at Portland State University and especially this project. I also want to express my gratitude, in addition to Dr. Monsere, to Dr. Robert L. Bertini and Dr. Jennifer Dill for being instrumental in keeping my interest in transportation engineering alive and well. Additionally, I would like to acknowledge the rest of my professors and classmates who encouraged me throughout graduate school.

I would like to express my sincere gratitude to my $\mathrm{CH} 2 \mathrm{M}$ Centennial Project team for providing me with the opportunity and resources to evaluate the City's Neighborhood Traffic Management Program.

Finally, I want to thank my amazing parents Fidel Melgoza and Sara Melgoza, my brother Fidel Melgoza II, my sister-in-law Clara Melgoza, my grandparents, all my aunts and uncles, and cousins for their endless support to keep dreaming big and to dream even bigger. Estaré siempre muy agradecido. Los quiero mucho. Lastly, I want to thank all of my friends and colleagues who have helped me throughout the years in many different ways to achieve this goal; Ever Cervantes, William Atkins, Benjamin Milster, Angela Agee, Janely Griffith, Jayson Vucovich, Lisa Patterson, Leah Tomlinson, Todd Johnson, Max Gummer, David Ruelas, Shirley Grayson, Shannon O'Quinn, Alejandro Rodriguez, Gabriel Morales, and Eric Pogue. I love you all. 


\begin{abstract}
An abstract of the research project report of Rolando Melgoza for the Master of Science in Civil and Environmental Engineering submitted on May 28, 2015.

Title: An Evaluation of the Neighborhood Traffic Management Program of Centennial, Colorado
\end{abstract}

Residential neighborhoods throughout the United States seek to maintain a quality of life where residents can live free of traffic factors adversely affecting their safety. Many communities have adopted a Neighborhood Traffic Management Program (NTMP) to address concerns over cutthrough traffic, speeding, and safety. The City of Centennial, Colorado, incorporated in 2001, is a young city and has its own NTMP. Four traffic mitigation projects have been implemented. The objective of this research is to conduct a before and after comparison study of each Centennial NTMP project, to review the NTMP policies of American cities with similar suburban characteristics to Centennial, and to identify and recommend efficiency improvements to the Centennial NTMP policy. The study was conducted by organizing all of the original NTMP data beginning with the first project implemented in Centennial. This was the beforedata. The after-data were collected by replicating the data collection process, which included vehicle speeds, average daily traffic counts, and crash history. Speed and traffic volume data were collected with tube counters. Crash data are supplied by the Arapahoe County Sheriff's Office and are stored in Centennial's crash database. The data were analyzed using the Intersection Magic software. The NTMP policies from the other cities were obtained through their respective public works departments and city websites. This report presents the results of the effectiveness of the Centennial NTMP program goals, objectives, policies, and tools. The findings indicate that the Centennial NTMP needs a refocus to educate its citizens on the results of projects that have been implemented and are showing positive results. Additionally, some modifications to the existing policy, based on reviews of similar NTMPs, would improve the efficiency. 


\section{TABLE OF CONTENTS}

$\begin{array}{lll}1.0 & \text { Introduction } & 1\end{array}$

$\begin{array}{llr}1.1 & \text { Objectives } & 1\end{array}$

$\begin{array}{llr}1.2 & \text { Scope of Work } & 2\end{array}$

1.3 Organization $\quad 2$

$\begin{array}{lll}2.0 & \text { Background } & 4\end{array}$

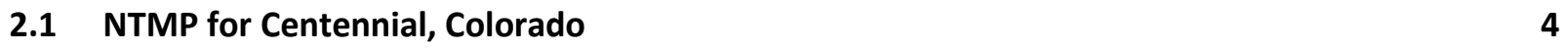

$\begin{array}{ll}2.2 & \text { NTSP of Lee's Summit, Missouri } \\ 2.3\end{array}$

2.3 NTMP of Scottsdale, Arizona $\quad 13$

2.4 NTMP of West Jordan, Utah $\quad 17$

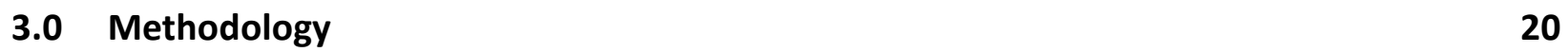

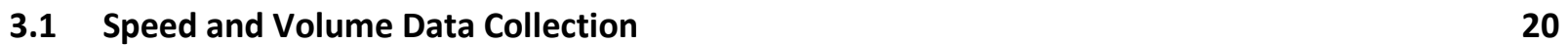

$\begin{array}{ll}3.2 & \text { Intersection Magic }\end{array}$

$\begin{array}{llr}3.3 & \text { Statistical Test } & 21\end{array}$

$\begin{array}{lll}3.4 & \text { Cut-Through Study } & 21\end{array}$

3.5 NTMP Policy and Project Review $\quad 22$

$\begin{array}{lll}4.0 & \text { Analysis } & 23\end{array}$

$\begin{array}{lll}4.1 & \text { Fox Ridge NTMP } & 23\end{array}$

E. Mineral Avenue $\quad 23$

E. Otero Avenue $\quad 29$

Park Borough - E. Dorado Avenue $\quad 35$

4.2 Highlands 460 - E. Otero Avenue and S. Adams Street 41

5.0 Conclusions $\quad 50$

5.1 Challenges $\quad 50$

5.2 Recommendations $\quad 51$

5.3 Future Research

$\begin{array}{lll}6.0 & \text { References } & 54\end{array}$ 


\section{LIST OF TABLES}

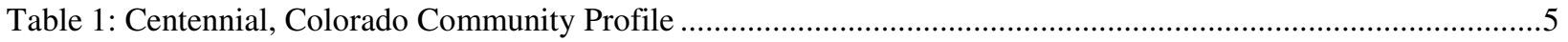

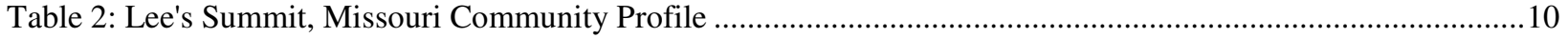

Table 3: Scottsdale, Arizona Community Profile ............................................................................................... 13

Table 4: West Jordan, Utah Community Profile ................................................................................................. 17

Table 5: Fox Ridge-Mineral 85th Percentile Speeds ....................................................................................24

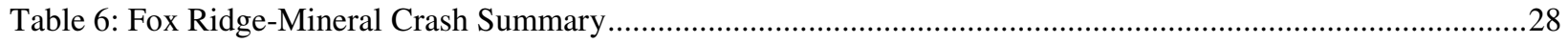

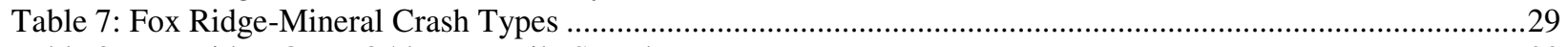

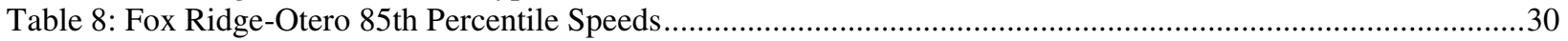

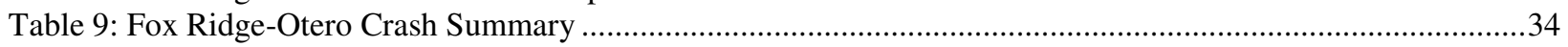

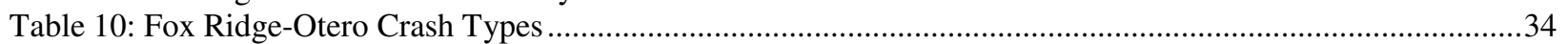

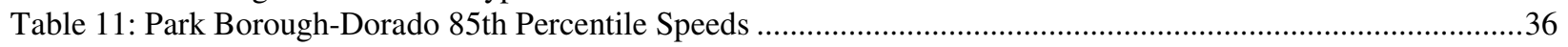

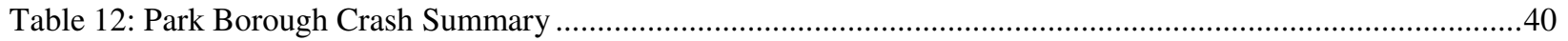

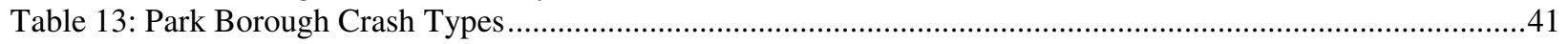

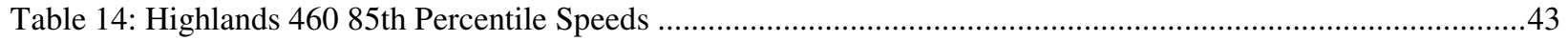

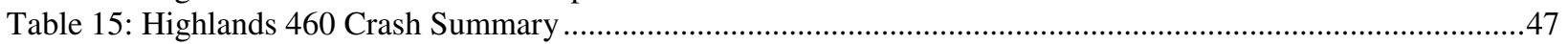

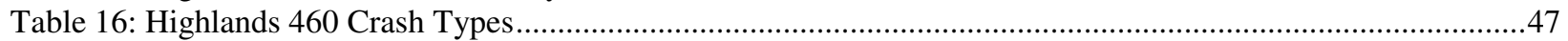




\section{LIST OF FIGURES}

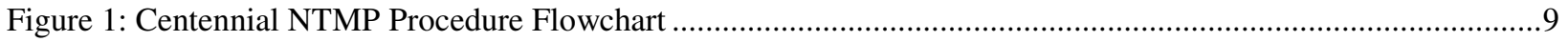

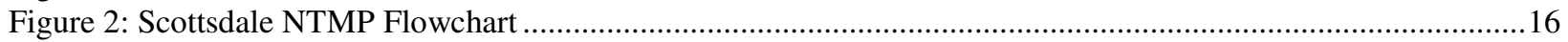

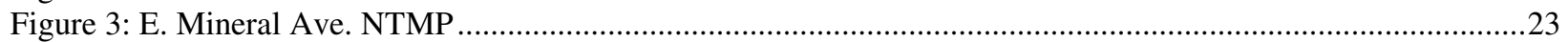

Figure 4: E. Mineral Ave. Roadway Narrowing Typical Section.....................................................................24

Figure 5: Eastbound Mineral e/o Magnolia Speeds \& Volume ..........................................................................25

Figure 6: Westbound Mineral e/o Magnolia Speeds \& Volume ..............................................................26

Figure 7: Eastbound Mineral e/o Olive Speeds \& Volume ........................................................................27

Figure 8: Westbound Mineral e/o Olive Speeds \& Volume ......................................................................28

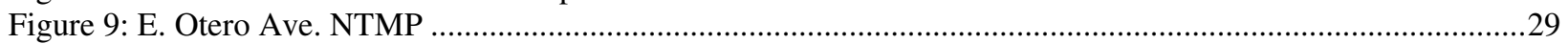

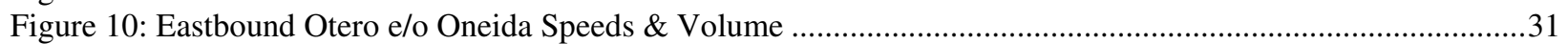

Figure 11: Westbound Otero e/o Oneida Speeds \& Volume .........................................................................32

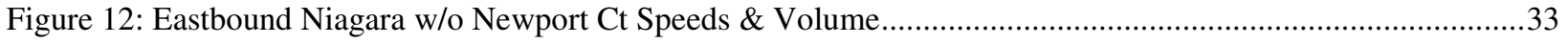

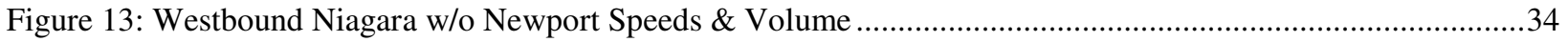

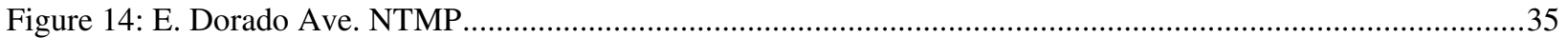

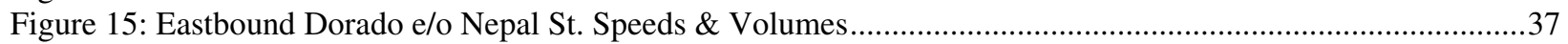

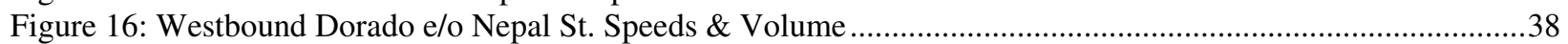

Figure 17: Eastbound Dorado w/o Perth Pl. Speeds \& Volume .........................................................................39

Figure 18: Westbound Dorado w/o Perth Pl. Speeds \& Volume .......................................................................40

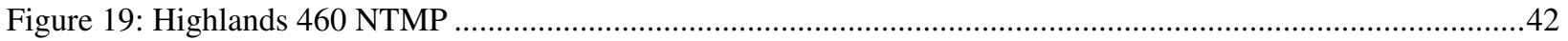

Figure 20: Northbound Adams s/o Madison Cir. Speeds \& Volume .............................................................43

Figure 21: Southbound Adams s/o Madison Cir. Speeds \& Volume .............................................................44

Figure 22: Eastbound Otero e/o Phillips Dr. Speeds \& Volume........................................................................45

Figure 23: Eastbound Otero Ave. e/o Phillips Dr. Speeds \& Volume ...................................................................46 


\subsection{INTRODUCTION}

Neighborhood residents enjoy the safety and livability of their communities. The balance between these quality of life benefits and maintaining mobility often clash due to increased traffic volume, which is often associated with noise, pollution, and speeding. The concept of traffic calming provides an ongoing practice to address these issues.

Traffic calming traces its roots to the first known deliberate attempt at reducing a threat to the livability of a neighborhood in Delft, The Netherlands during the 1960s (1). Residents of the Dutch city were frustrated with speeders and cut-through traffic. What was once a street that catered to the automobile, was turned into an obstacle course full of amenities built in the roadway right-of-way like shared spaces, tables, and benches. The concept is known as woonerven, which translates into English as "living yard". The woonerven or woonerf ideas spread throughout The Netherlands into countries all around the world including the United States. According to a literature survey conducted in 1999 by the University of California Berkeley, over 350 municipalities across the United States had attempted some type of traffic calming (1).

The City of Centennial, Colorado was incorporated 14 years ago in February 2001 and began its Neighborhood Traffic Management Program (NTMP) in 2007. The implementation of any traffic calming planning requires a plan with guidelines and a monetary budget. Many cities have created NTMPs, which are approved and adopted by the respective jurisdictions to address traffic calming. Each plan is specifically catered to the needs of the community and varies by different factors relating to politics, culture, previous lessons learned, climate impacts, and setting.

\subsection{Objectives}

The purpose of this research is to conduct a review of the Centennial NTMP. The first step is to review three NTMP policies from cities across the United States with a goal of determining what has and has not worked in those municipalities. Second is to replicate the data collection process for the Centennial NTMP projects that have been constructed, and generate much needed afterresults to compare against the before-results. Finally, the end goal is to take lessons learned from the other NTMP policies and the Centennial NTMP projects to recommend improvements to the Centennial NTMP policy. 


\subsection{Scope of Work}

This research examined the NTMP policies of three American cities obtained through their websites. The cities are Lee's Summit, Missouri; Scottsdale, Arizona; and West Jordan, Utah. The selection of these cities was based on several factors and includes one or more of the following characteristics: density similar to that of Centennial, suburban setting and proximity to large metropolitan area, different geographic locations to include a variety of climate conditions which may impact the traffic mitigation options, and because different traffic cultures exist throughout the United States. What is an acceptable traffic calming device in West Jordan, Utah may not have political support by locals in Scottsdale, Arizona or Lee's Summit, Missouri, for example. The research intentionally did not include dense urban areas because the lessons learned from those settings would be difficult to apply to Centennial. The research also did not focus on NTMP project financial budgets.

The first project of the Centennial NTMP was in 2008. The most recent project at the time of research is still in the planning phase in 2015. The data sets for the projects that have been built and implemented from 2008 to present were obtained to produce a before and after study for each one. The Centennial projects lacked after-results to measure their effectiveness. Speed and volume data is collected with traffic tube counters. Crash data is provided by the Arapahoe County Sheriff's Office, maintained by Centennial Public Works, and analyzed using the software program Intersection Magic. Cut-through data were collected manually. Attention was placed on ensuring data sets represent the most normal conditions, meaning traffic counts were only conducted Tuesdays through Thursdays on non-holidays, severe weather days such as snow were excluded, and data collection dates were only during the academic school year.

The Centennial NTMP process will benefit from this research because local project results have a greater meaning to residents. Centennial residents are more concerned with the effectiveness of traffic calming devices in their own community. The results obtained in this research will help guide the collaborative decision making process in future NTMP projects.

\subsection{Organization}

The following chapter presents a brief history of traffic calming and a review of six NTMP policies. The methodology section explains how the work was conducted and which data were 
used. The analysis section explores the Centennial NTMP projects completed since the adoption of the policy by the City. The before and after study results demonstrate the level of effectiveness of the projects. The final section provides conclusions, recommendations, and ideas for future work. 


\subsection{BACKGROUND}

Neighborhood Traffic Management Programs have been developed in cities throughout the United States. The leaders and residents of these cities hope to maintain the livability and safety of their communities. These important quality of life traits can be a challenge to retain as a result of various factors that include increased traffic noise and traffic safety concerns.

The City of Centennial, Colorado is a young city and is located in the Denver, Colorado metropolitan area. At its time of incorporation in February 2001, Centennial was the largest incorporation in the United States with an initial population of approximately 100,000 residents (3). Since 2001, Centennial has experienced many changes and growth from population, traffic volume, job and retail, and new land annexations. The city has received several honors such as the Denver Regional Council of Governments' Live, Work, Play People's Choice Award for the Centennial Center Park in 2013, a $26^{\text {th }}$ ranking in 50 Best Places to Live by USA Today, and a $13^{\text {th }}$ place ranking of 50 Best Places to Live in America by Money Magazine (3). Most recently, Centennial was among a select few cities awarded a Bloomberg Philanthropies Innovation Team Grant to develop and deliver bold new approaches to community issues including affordable housing, public safety, infrastructure finance, customer service, and job growth (4).

The NTMPs from American cities and municipalities were selected for review based on similar suburban characteristics to Centennial including population, location in a major metropolitan area, density, and existing traffic mitigation policies in place from which project results could be evaluated. The following is a summary of the of NTMP policies from Lee's Summit, Missouri; Scottsdale, Arizona; and West Jordan, Utah.

\subsection{NTMP for Centennial, Colorado}

Community Profile (5), (6)

\begin{tabular}{|l|l|}
\hline State & Colorado \\
\hline Population 2013 & 106,114 \\
\hline Population, percent change 2010-2013 & $5.6 \%$ \\
\hline
\end{tabular}




\begin{tabular}{|l|l|}
\hline Average annual precipitation (inches) & 14.30 \\
\hline Average annual snowfall (inches) & 53.80 \\
\hline Land Area (square miles) & 28.72 \\
\hline Persons per square mile & 3,495 \\
\hline
\end{tabular}

Table 1: Centennial, Colorado Community Profile

The City of Centennial NTMP was created in response to a growing number of resident concerns regarding speeding and cut-through traffic. The City started off with the Interim Traffic Calming Policy before officially adopting the current NTMP policy. This policy differed from the previous one in that it clearly stated program goals, objectives, policies, and a traffic mitigation toolbox. Typically, the City selects one NTMP project per year and a budget of $\$ 50,000$ is allocated for that project.. Any project that exceeds that amount can be considered for additional funds in the Capital Improvement Program, but the NTMP project will have to compete against other non-NTMP projects citywide. Additionally, the selected NTMP neighborhood may choose to utilize their own money, such as from a homeowners association (HOA), to fund the project.

\section{Purpose}

The Centennial NTMP goal is as follows, "To provide a consistent, feasible, and manageable procedure for safely addressing neighborhood traffic concerns on residential streets where a documented speeding problem, unacceptable cut-through volume, or other traffic factors adversely affecting residential safety exist."

\section{Eligibility}

All residents of Centennial are eligible to apply for the NTMP.

\section{Policies}

The NTMP policy states that all projects will be implemented following guidelines from all engineering guidelines such as the Manual on Uniform Traffic Control Devices (MUTCD), the 
American Association of State Highway and Transportation Officials (AASHTO), and any of the current design and construction standards adopted by the City of Centennial and Colorado Department of Transportation.

\section{Emergency Response and Street Classification}

Centennial engineers coordinate with emergency response services to ensure that reasonable access is preserved in any NTMP project. Additionally, the roadway must be a residential street and not classified as a minor or principal arterial road. Snow routes must remain passable to snow equipment, which may limit the specific traffic mitigations available on such routes.

\section{Landscaping}

When structural treatments such as bulb outs or neckdowns are used in projects, landscaping becomes more important because it works to enhance the effectiveness of the traffic mitigation by visually narrowing the street. All landscape treatments become the responsibility of the HOA under a maintenance and license agreement. The City may choose to provide service to NTMP project landscaping in the absence of an HOA.

\section{Toolbox of Devices}

The Centennial NTMP has identified several toolbox devices for use in a project. Not every device is appropriate for every neighborhood. The selection of these devices is intended to provide a wide range of options and flexibility to residents both in complexity and costs. The toolbox devices are as follows:

Neighborhood Education Programs
Restricted Movement Signing
Enhanced At-Grade Pedestrian Crossing
Speed Monitoring Display
Entry Islands
Speed Hump
Curb Extensions
Traffic Circles
Raised Intersection
Realigned Intersection

Speed Limit Signing Truck Restriction Signing Striping/Visual Narrowing Traditional Police Enforcement Entrance Barrier Raised Pedestrian Crossing Medians Restricted Movement Barrier Curvilinear Street 


\section{Procedure}

\section{Phase 1 - Project Initiation}

Neighborhoods have several options to introduce the problem area to the Centennial Traffic Engineer Services (TES). Individual residents can fill out an application where they summarize the concern and commit to being the neighborhood representative should the project receive funding. The HOA groups can form a committee and apply. The City's own staff can nominate streets for the program. And finally, the City Council can initiate a project.

During Phase 1, TES will identify the physical boundaries of the project. Residents often send in suggestions for traffic mitigation improvements with their applications and therefore staff will use this as a way to determine if additional streets need to be included in the project. TES collects data about the neighborhood street that includes traffic speed and volume, geometric constraints, and a 3-year crash history.

Each application is first evaluated to determine if it meets the minimum threshold. The requirements are as follows:

- The average daily traffic (ADT) must be greater than 500 vehicles per day (vpd) or have at least 20 percent cut-through traffic.

- The adjacent pedestrian generators must have an $85^{\text {th }}$ percentile speed $7 \mathrm{mph}$ or greater above the posted speed limit on the subject roadway.

- The roadway must have a crash history of three or more correctable crashes in a one-year period.

\section{Phase 2}

During Phase 2, TES educates the neighborhood on the reality of their request. Temporary speed signs are installed to display speed to drivers. If warranted, additional speed signs are added to the roadway. Additionally, the Arapahoe County Sheriff's Office (ACSO) is brought into the discussion and may result in police enforcement along the roadway. 


\section{Phase 3}

In the final phase, one project is selected (additional projects will depend on funding availability) based on rankings against the other applicants. The original applicant(s) is/are contacted. TES conducts two public meetings with residents. The first meeting focuses on educating residents of the NTMP process, gathering additional information from residents regarding the neighborhood problem, and getting a sense of which toolbox items have some public support to develop alternatives. The second meeting focuses on those alternatives and finalizing a traffic mitigation plan for the ballot. The ballot is designed to be a yes/no vote on one option, not selecting between multiple options. For the project to be implemented, a minimum of 50 percent of the affected residents must participate in the voting process. Of that 50 percent, two-thirds of respondents must be in favor of the project by indicating a "yes" vote. Neighborhoods that fail to pass the option will result in no project implementation and a moratorium that will not allow the neighborhood to apply to the NTMP for two years.

Interestingly, the final phase in the Centennial NTMP policy does list an after study. The after study is to gauge the effectiveness of the implemented traffic mitigation. Plans that satisfy performance measures are completed, but those that do not should be reevaluated by TES. 


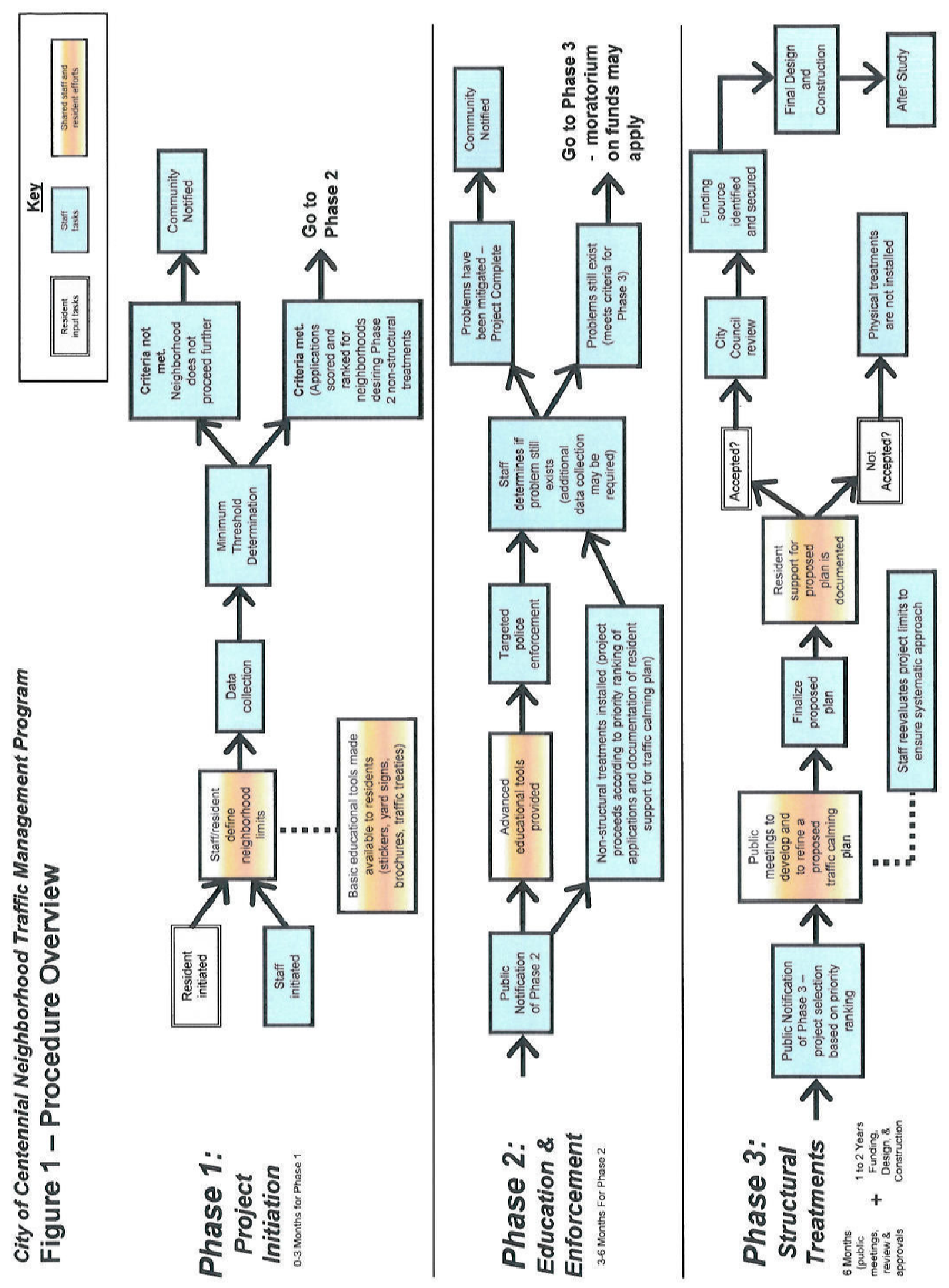

Figure 1: Centennial NTMP Procedure Flowchart 


\subsection{NTSP of Lee's Summit, Missouri}

Lee's Summit, Missouri is a suburb in the southeast corner of the bi-state Kansas City Metropolitan Area. The proximity to Kansas City and easy access to Interstate 470 led to significant growth in the 1990s as one of the fastest growing cities in Missouri. Today, Lee's Summit is transitioning from a bedroom community to a larger city with new retail and employment opportunities.

Community Profile (5), (6)

\begin{tabular}{|l|l|}
\hline State & Missouri \\
\hline Population 2013 & 93,184 \\
\hline Population, percent change 2010-2013 & $2.0 \%$ \\
\hline Average annual precipitation (inches) & 43.41 \\
\hline Average annual snowfall (inches) & 18.80 \\
\hline Land Area (square miles) & 63.35 \\
\hline Persons per square mile & 1,442 \\
\hline
\end{tabular}

Table 2: Lee's Summit, Missouri Community Profile

The Lee's Summit Neighborhood Traffic Safety Program (NTSP) was implemented to involve its residents to continue the City's commitment to safety and livability. The program is an effort between Public Works, Lee's Summit Police, and the fire department.

\section{Project Initiation}


Several options exist for Lee's Summit residents and staff to initiate a project. Residents or an HOA may submit an application accompanied by a petition showing a minimum of 50 percent of the affected residents in support of traffic mitigation. The resident prepares the application and the petition is prepared by staff but distributed by the resident. Additionally, police, fire department, schools, other agencies, or City staff may send in applications.

\section{Public Meeting}

City staff will hold a neighborhood meeting (organized by applicant) to present the findings of a traffic study. Meetings will take place regardless of the results of the study showing or not showing a problem. The City focuses on the "three E's" of neighborhood traffic safety: education, enforcement, and engineering.

\section{Education}

Not every application will qualify for funding to implement traffic mitigation. Sometimes residents have a perception of a problem that does not exist. Educating residents helps them understand what the actual $85^{\text {th }}$ percentile speeds are compared to what they think they are. Resources also include a speed trailer, informational pamphlets, government access media channel, and a radar loan program.

\section{Enforcement}

The Lee's Summit Police Department may provide scheduled traffic enforcement in problem areas. If the violations persist, the area can be classified as a Neighborhood Traffic Enforcement Zone. This classification requires permanent signs and results in higher fees for violators.

\section{Engineering}

The engineering portion of the NTSP is the most in-depth of the "three E's". Traffic calming treatments involve retrofitting the existing roadway with items found in the traffic calming toolbox.

\section{Traffic Calming Toolbox}


Horizontal Deflection

Bulb-Outs

Center Island Narrowing

Chicanes

Chokers/Slow Points

Full Diverter
Gateway Treatment

Median Barriers

Oval Median

Traffic Circle

Two-Lane Slow Point

Vertical Deflection

Raised Crosswalks

Speed Tables

Raised Intersections

Speed Cushions

Speed Humps

\section{Qualifications}

The NTSP has criteria for which roadways are eligible for traffic calming and are as follows:

- Street classified as local or residential collector,

- Street does not exceed two travel lanes or 40-foot pavement width,

- Street has a horizontal curve of 300-foot radius or greater,

- Street has vertical curve with adequate stopping sight distance (SSD),

- A grade not exceeding 8 percent,

- Wheel-base vehicles no more than five percent long,

- Route is not used frequently by emergency responders,

- Route is not a city bus route.

\section{After Study}


The NTSP will evaluate the results of a traffic mitigation project after a three-year period if the project resulted in negative impacts to the project neighborhood or to an adjacent neighborhood. Residents have to submit a petition signed by 65 percent of affected residents for modification or removal. The City will begin a process of meeting with residents and determining the best course of action. Removal of the traffic mitigation will require 75 percent of affected resident signatures. Removing traffic calming devices will place a moratorium on the neighborhood for five years.

\subsection{NTMP of Scottsdale, Arizona}

Community Profile (5), (6)

\begin{tabular}{|l|l|}
\hline State & Arizona \\
\hline Population 2013 & 226,918 \\
\hline Population, percent change 2010-2013 & $4.4 \%$ \\
\hline Average annual precipitation (inches) & 9.37 \\
\hline Average annual snowfall (inches) & Rare \\
\hline Land Area (square miles) & 183.92 \\
\hline Persons per square mile & 1,182 \\
\hline
\end{tabular}

Table 3: Scottsdale, Arizona Community Profile

The Scottsdale NTMP also focuses on the "three E's" with a goal of maintaining the City's neighborhood quality of life.

\section{Eligibility}


The NTMP is open to all Scottsdale residents with valid photo identification who are 18 years and older in age. The applicant must have an additional person for help with the first stage of the program.

Speed Awareness Program (SAP)

The SAP serves as an education tool for residents and drivers, as often drivers are not aware of their speeds. The first part of the SAP is divided into two parts. The applicants work with the police department throughout the SAP. The first step is the education component and includes holding a neighborhood meeting with affected residents, deploying a speed trailer in the neighborhood, conducting radar tracking, and installing warranted signs along the roadway. During radar tracking, speed violators receive a letter in the mail, but not a ticket with a fine. The letter educates the drivers on the importance of speed compliance. The second step involves enforcement where the police department does distribute tickets with fines to violators.

Following the completion of the SAP, residents have the option to pursue physical installations to the roadway. The project process (the engineering component of the "three E's") is as follows:

- Applicant completes an interest form (an application to the program),

- The transportation and emergency responders such as fire department approve of the street as an eligible candidate for traffic calming,

- The City staff evaluates the street for qualifying criteria that includes speeds and volume.

The process has two categories of traffic calming devices:

- Non-route restricting

- Speed tables

○ Roundabouts

○ Chokers

- Median islands 
- Chicanes

- Route restricting and closures

- Diagonal diverters

- Forced turn islands

- Median barriers

The process for the Scottsdale NTMP is shown on the following page as a flowchart in Figure 2. 


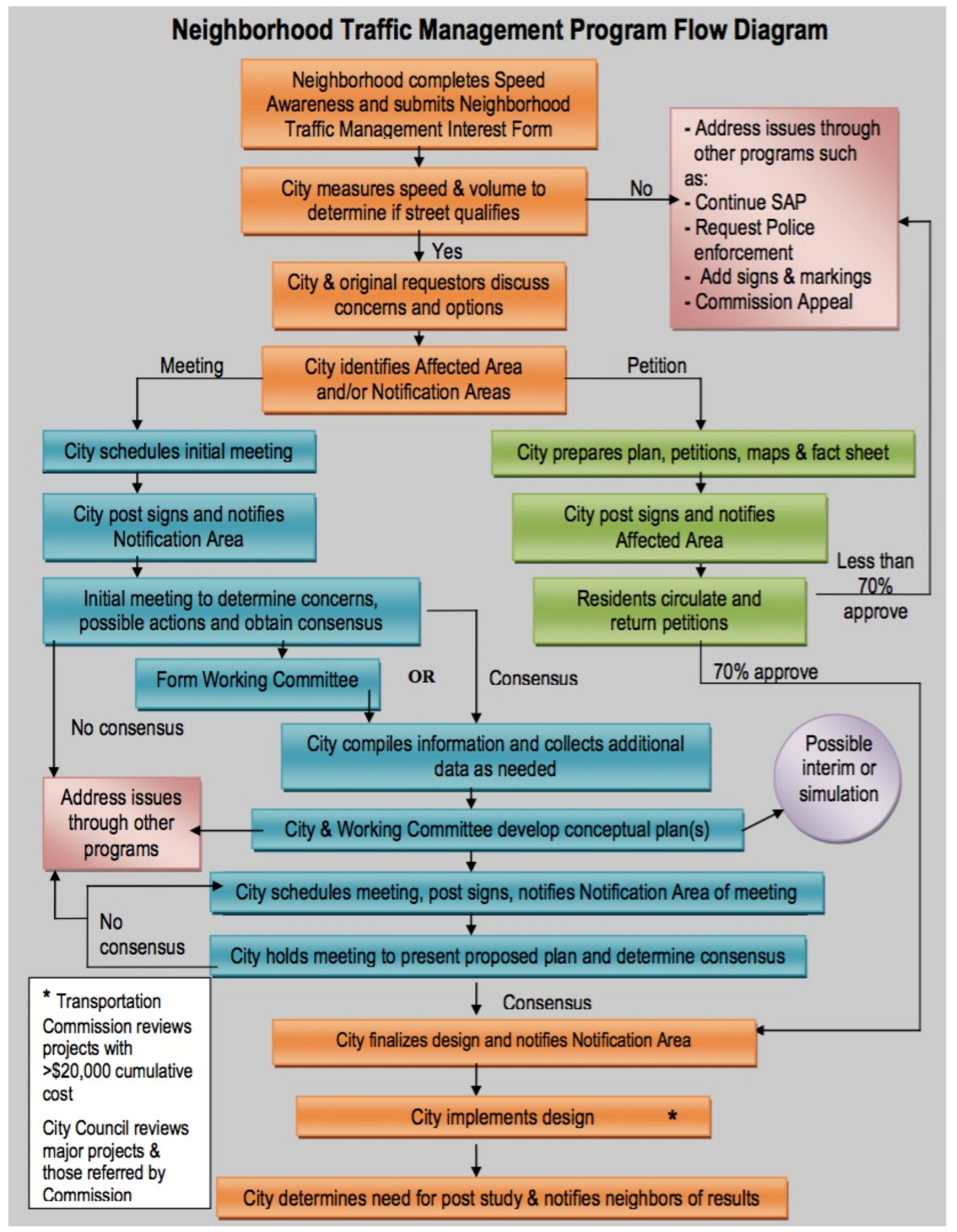

Figure 2: Scottsdale NTMP Flowchart 


\section{After Study}

City of Scottsdale staff will collect speed and volume data six months after project implementation. The success (or lack of) is determined by comparing the after results of the study against the original minimum threshold. If the project no longer meets the minimum threshold, it is considered a success. Additionally, residents have the opportunity to request modifications or removal of the traffic calming device(s). These requests must follow the same procedures as when the first application was submitted. For example, if a petition was used to apply to the NTMP program, another petition must be used to modify the devices.

\subsection{NTMP of West Jordan, Utah}

West Jordan, Utah is located in the Salt Lake City metropolitan area along the Wasatch Front. The city lists its NTMP on the official West Jordan website in a section for neighborhood programs which include neighborhood dumpster program, Adopt-A-SPOT program, landscape irrigation, and scout packet.

Community Profile (5), (6)

\begin{tabular}{|l|l|}
\hline State & Utah \\
\hline Population 2013 & 110,077 \\
\hline Population, percent change 2010-2013 & $6.1 \%$ \\
\hline Average annual precipitation (inches) & 16.10 \\
\hline Average annual snowfall (inches) & 56.20 \\
\hline Land Area (square miles) & 32.46 \\
\hline Persons per square mile & 3,195 \\
\hline
\end{tabular}

Table 4: West Jordan, Utah Community Profile 
The West Jordan NTMP was created in response to the City's and residents' desire to maintain a high level of livability. According to the NTMP policy, West Jordan seeks "a balanced relationship between multiple uses and needs of a neighborhood." The outcomes of all NTMP projects must support the policies found in the West Jordan Master Transportation Plan.

\section{Eligibility}

The West Jordan NTMP is open to all residents. Requests can be submitted by individual residents or by an HOA. The application must demonstrate support from at least 10 residents of the affected area.

\section{Ranking}

The NTMP applications are ranked based on the following criteria with the maximum score shown in parentheses:

- $\quad$ Traffic volume (30)

- $\quad$ Speed (violation rate) (20)

- Crashes (20)

- Elementary schools (5 for each school within 200 feet of the street being evaluated)

- Other extraordinary circumstances (5 points for each pedestrian oriented facility, 1 point for each school bus stop, 5 points maximum for public city project which may negatively impact the livability of the neighborhood)

- Designated pedestrian routes (5 points for intersecting Safe Routes to School route)

A minimum of 40 points is required to be considered for the program.

Neighborhood Traffic Management Devices

Mini-roundabouts

Closures

Chokers or curb extensions
Semi-diverters Intersection channelization Raised crosswalks/Speed Humps 


\section{Plan Development}

City staff meets with residents at a neighborhood meeting to gather more information about the application and the problem. Different from the previous NTMPs examined, a committee of 6 residents is formed to identify the problems, alternatives and solutions, and a proposed plan.

\section{Test Installation and Project Evaluation}

One of the unique features of the West Jordan NTMP is the temporary test installation. Once the committee has identified an alternative traffic calming solution, the City will install a test traffic calming device on-site for a 4- to 12-month period. Once the test period is complete, the residents are surveyed to gauge the level of satisfaction. Residents must show 51 percent in favor of the proposed solution. If residents are not satisfied, modifications can be made to the test and rerun. If residents are satisfied, the test device is designed as a permanent device and taken to the city council. Upon city council approval, the project moves to the design and construction stage.

\section{After Study}

One year after the installation of the permanent traffic calming device, City staff will study the project again to determine its effectiveness. Should the neighborhood decide to remove the devices, they must demonstrate that 51 percent of affected residents support the removal. 


\subsection{METHODOLOGY}

This chapter describes the reasoning for the selection of the Centennial NTMP projects evaluated in this research. This is followed by a description of traffic speed and volume data collection, the Intersection Magic crash analysis software, the cut-through study procedure, and the NTMP policy reviews.

\subsection{Speed and Volume Data Collection}

The speed and volume data was collected by the same methods as all Centennial NTMP data has been collected in the past. Data is collected for 48-hours. The data were averaged to obtain a 24hour count. The $85^{\text {th }}$ percentile is an industry standard used to measure speeds. Drivers will operate their vehicles in a reasonable and safe manner. In other words, they will drive at a speed that feels comfortable to them, while 15 percent of drivers will exceed the $85^{\text {th }}$ percentile speed. To be conservative in analyzing the NTMP projects, the highest $85^{\text {th }}$ percentile speed is used for each direction.

Traffic counter tubes provided by a contractor were used for all data collection. The placement of each tube was determined by reviewing maps and location descriptions. Each location was verified in the field prior to the deployment of the tubes to ensure a structure such as a fence post or signpost existed to secure the tubes. Additionally, a quality check was performed to ensure tubes were placed in the correct location. An incorrect placement of a tube would have resulted in unreliable data that could not be used for comparison. The tubes were placed in the field under the following conditions:

- Only on weekdays (Tuesday, Wednesday, and Thursday),

- Not during any holiday, nor the day preceding or immediately following a holiday,

- The Littleton Public Schools and Cherry Creek School District, which serve Centennial students, are in session,

- No lane closures on adjacent arterials from construction projects which may divert traffic to neighborhood streets,

- No crash incidents that may also divert traffic to neighborhood streets. 
- No severe weather such as snow that would impact school traffic as well as slow down vehicle speeds.

\subsection{Intersection Magic}

Intersection Magic, created by Pd' Programming, is a Microsoft Windows application for crash records analysis. Several jurisdictions in the Denver Metropolitan Area and around the country use the software. Among the many capabilities of Intersection Magic, it can create collision diagrams, high crash location lists, corridor analyses, and frequency reports. The crash data is obtained monthly from the Arapahoe County Sheriff's Office (ASCO) and uploaded to the Centennial crash database. The database has crash data from January 2, 2007 through the most recent date May 8, 2015. ASCO reports data based on block numbers. The block numbers are part of the Greater Denver address grid. However, investigators query the database to identify specific intersections rather than block numbers. Crash reports to citizens need to be stated in terms of street names, not block numbers. Therefore, each month, the ASCO data that is received in terms of block numbers undergoes a conversion (utilizing Microsoft Excel and Access) that translates the data from block numbers to actual street names. Since NTMP projects involve a neighborhood corridor and not just a single intersection, corridor cross streets were defined in Intersection Magic for each of the projects. The queries identified the following data for each project: number of crashes, crash date, type (property damage only, injury, fatality), daytime vs. nighttime, and nearest cross street in corridor.

\subsection{Statistical Test}

A chi-square test was used to determine the statistical significance of changes in speed distributions for the Highlands 460 NTMP. The chi-square test determines if the variation in speeds is statistically significant based on differences between observed and expected values.

\subsection{Cut-Through Study}

A cut-through study was performed by collecting license plate numbers during the A.M. peak period to match the parameters of the cut-through study conducted in 2013. License plate numbers were recorded from 7:30 A.M. to 8:30 A.M. The average travel time through the neighborhood was calculated by conducting travel runs. The license plate numbers were matched from the ingress and egress data for vehicles traveling through the neighborhood within the 
average travel time. The cut-through traffic is determined by dividing the total number of license plate numbers matched at both collection points by the total number of entering vehicles and reporting the result in percent.

\subsection{NTMP Policy and Project Review}

This research includes the review of the Centennial NTMP projects. Each section includes a section on the history of the project identifying the concern, a before and after study of traffic volumes and speeds, and crash history. 


\subsection{ANALYSIS}

\subsection{Fox Ridge NTMP}

This NTMP project involved two streets in the same neighborhood, E. Mineral Avenue and E. Otero Avenue. The Fox Ridge neighborhood selected electronic speed signs and lane narrowing using centerline and bike lane pavement markings from the NTMP toolbox to slow traffic. In addition, all crosswalk markings were replaced with new wider crosswalk bars. The speed limit on both streets is $30 \mathrm{mph}$.

\section{E. Mineral Avenue}

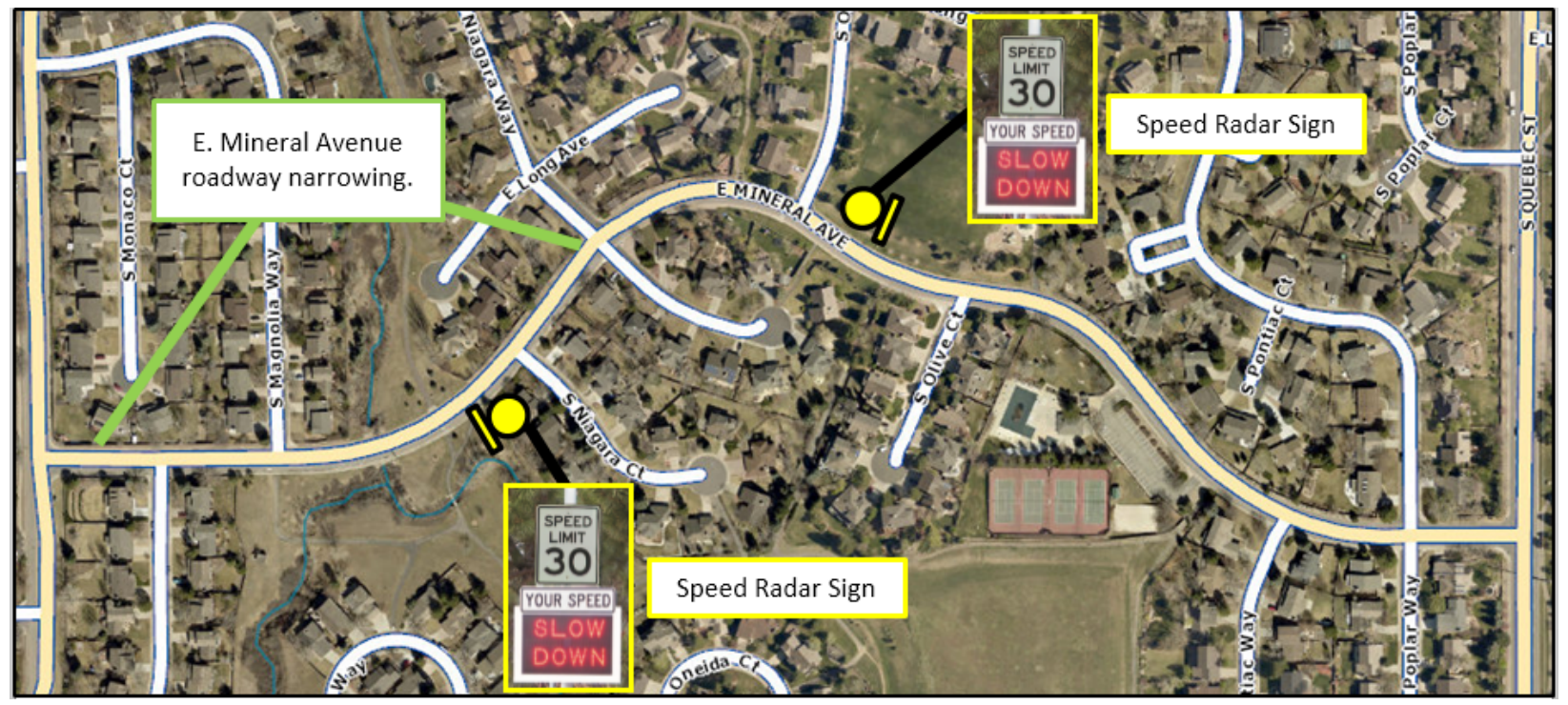

Figure 3: E. Mineral Ave. NTMP

The project extends the entire length of E. Mineral Ave. between S. Quebec Street and S. Monaco St. as shown in Figure 3. The locations for the signs were selected based on resident input and the elevation changes on that section of E. Mineral Avenue.

The roadway narrowing is shown in Figure 4. The roadway was striped to show a parking lane, bike lane, and travel lane. 


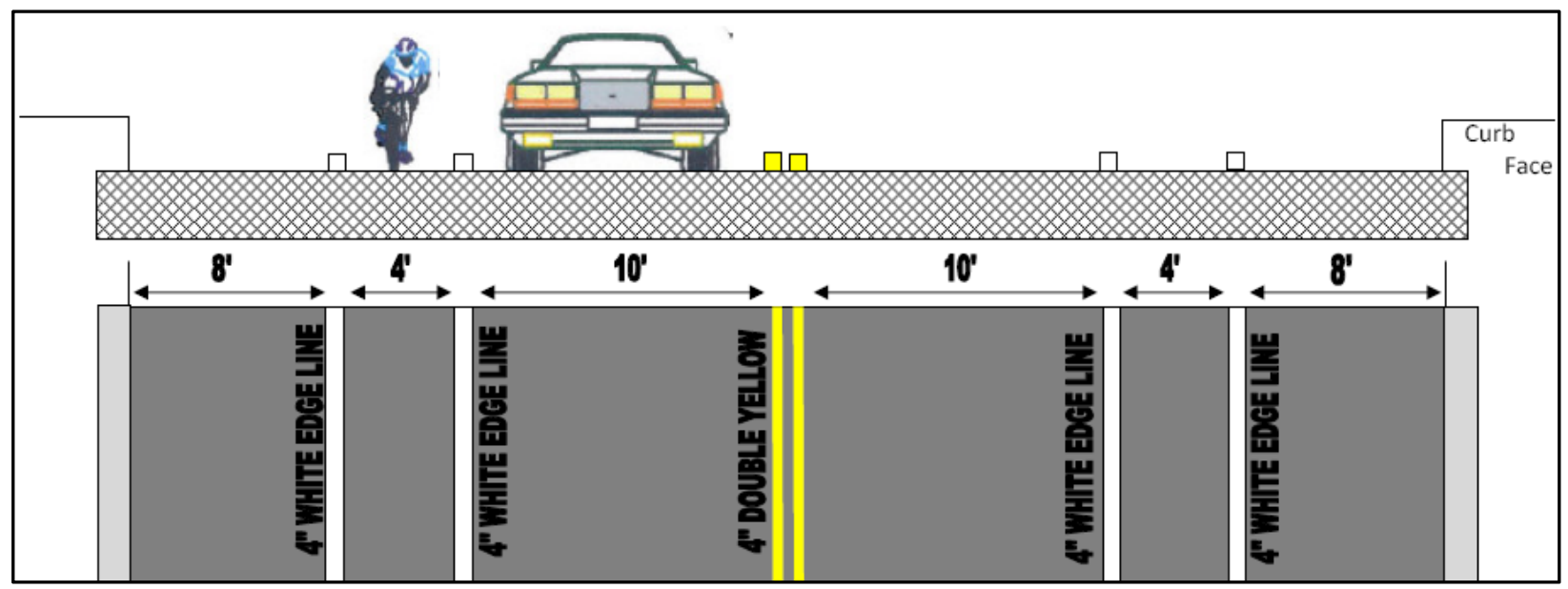

Figure 4: E. Mineral Ave. Roadway Narrowing Typical Section.

The before speed and volume data were collected on May 20, 2009. The after data were collected immediately following project implementation on September 30, 2009 and once more on May 15, 2015. The results are summarized in Table 5.

Fox Ridge-Mineral Ave. e/o Magnolia Way

\begin{tabular}{|l|c|c|c|c|c|c|}
\hline & $\begin{array}{c}\text { Volume } \\
\text { (ADT) }\end{array}$ & $\begin{array}{c}\text { 85th } \\
\text { Percentile }\end{array}$ & $\begin{array}{c}\text { Volume } \\
\text { (ADT) }\end{array}$ & $\begin{array}{c}\text { 85th } \\
\text { Percentile }\end{array}$ & $\begin{array}{c}\text { Volume } \\
\text { (ADT) }\end{array}$ & $\begin{array}{c}\text { 85th } \\
\text { Percentile }\end{array}$ \\
\cline { 2 - 7 } & \multicolumn{2}{|c|}{$5 / 20 / 09$ Before } & \multicolumn{2}{|c|}{$9 / 30 / 09$ After } & \multicolumn{2}{c|}{$5 / 14 / 15$ After } \\
\hline EB & 857 & $35 \mathrm{MPH}$ & 690 & $32 \mathrm{MPH}$ & 820 & $31 \mathrm{MPH}$ \\
\hline WB & 879 & $36 \mathrm{MPH}$ & 689 & $31 \mathrm{MPH}$ & 908 & $34 \mathrm{MPH}$ \\
\hline
\end{tabular}

Fox Ridge-Mineral Ave. e/o Olive Ct.

\begin{tabular}{|l|c|c|c|c|c|c|}
\hline & $\begin{array}{c}\text { Volume } \\
(A D T)\end{array}$ & $\begin{array}{c}\text { 85th } \\
\text { Percentile }\end{array}$ & $\begin{array}{c}\text { Volume } \\
\text { (ADT) }\end{array}$ & $\begin{array}{c}\text { 85th } \\
\text { Percentile }\end{array}$ & $\begin{array}{c}\text { Volume } \\
\text { (ADT) }\end{array}$ & $\begin{array}{c}\text { 85th } \\
\text { Percentile }\end{array}$ \\
\cline { 2 - 7 } & \multicolumn{2}{|c|}{$5 / 20 / 09$ Before } & \multicolumn{2}{|c|}{$9 / 30 / 09$ After } & \multicolumn{2}{|c|}{$5 / 14 / 15$ After } \\
\hline EB & 1179 & $34 \mathrm{MPH}$ & 1027 & $30 \mathrm{MPH}$ & 1073 & $29 \mathrm{MPH}$ \\
\hline WB & 1176 & $33 \mathrm{MPH}$ & 1103 & $29 \mathrm{MPH}$ & 1150 & $29 \mathrm{MPH}$ \\
\hline
\end{tabular}

Table 5: Fox Ridge-Mineral 85th Percentile Speeds

Both data locations show a drop in $85^{\text {th }}$ percentile speeds from May 2009 to September 2009. The after study in May 2015 shows that speeds have remained lower than the May 2009 speeds. Figures 5 through 8 show the speeds and volume for E. Mineral Avenue. 


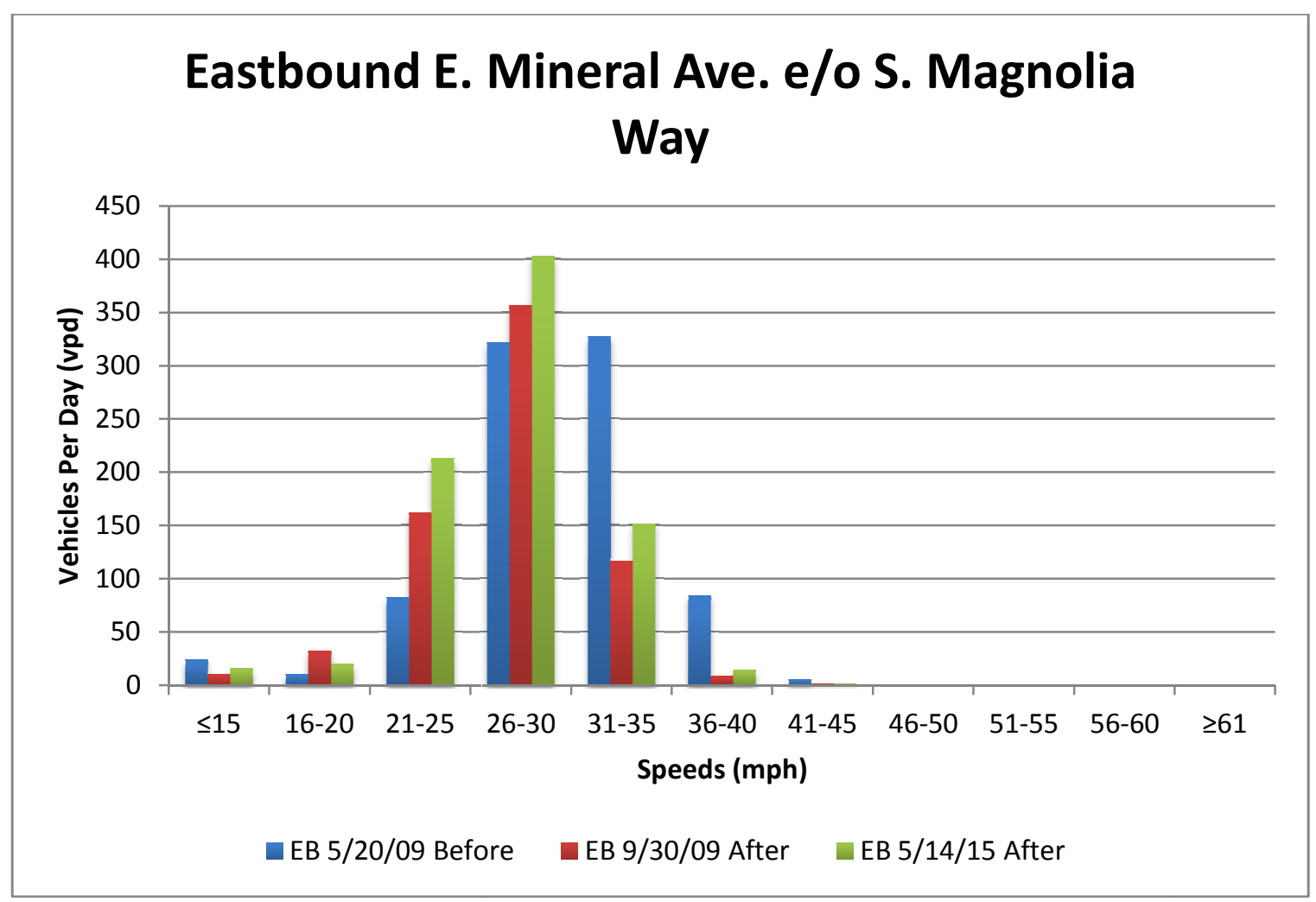

Figure 5: Eastbound Mineral e/o Magnolia Speeds \& Volume 


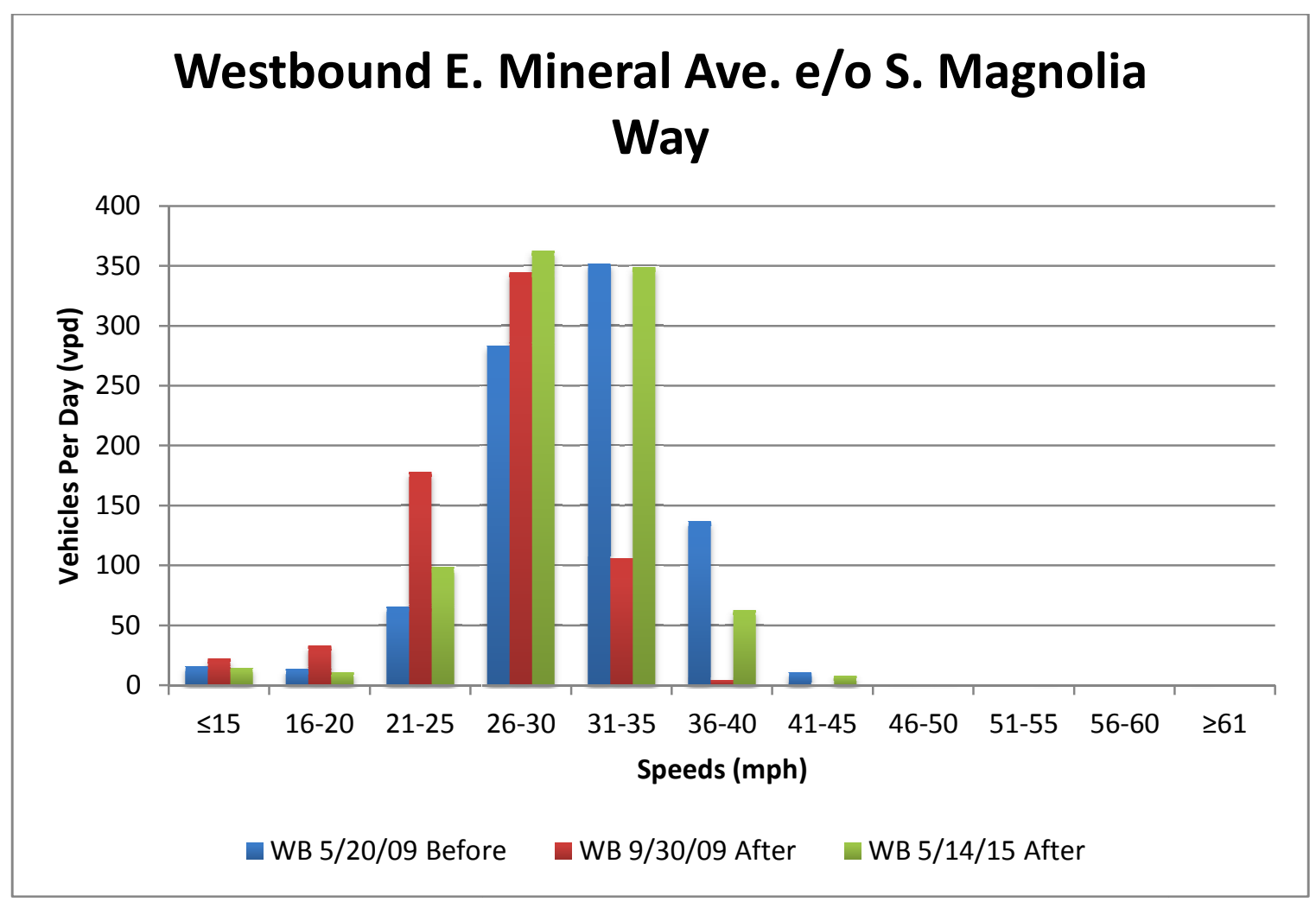

Figure 6: Westbound Mineral e/o Magnolia Speeds \& Volume 


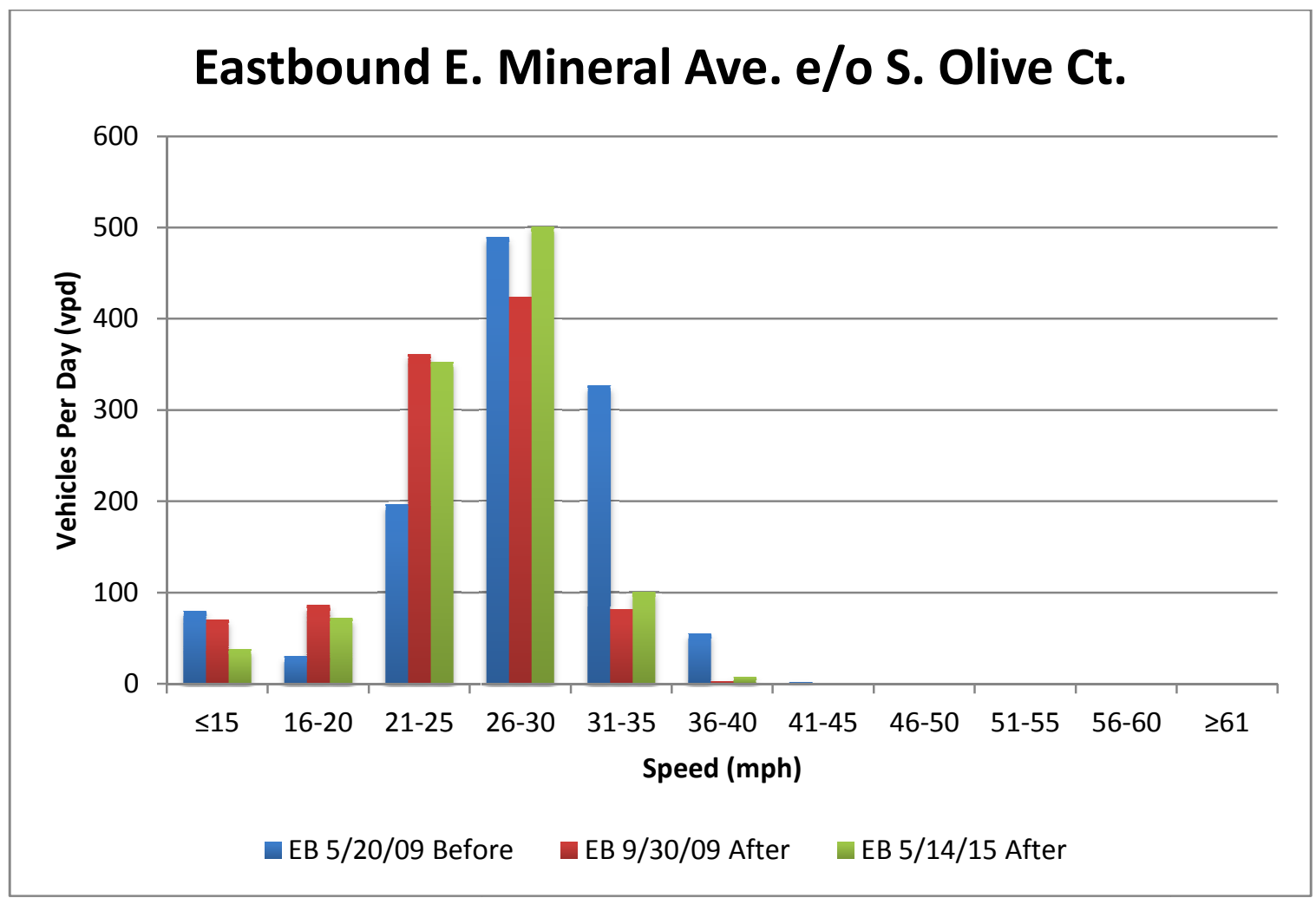

Figure 7: Eastbound Mineral e/o Olive Speeds \& Volume 


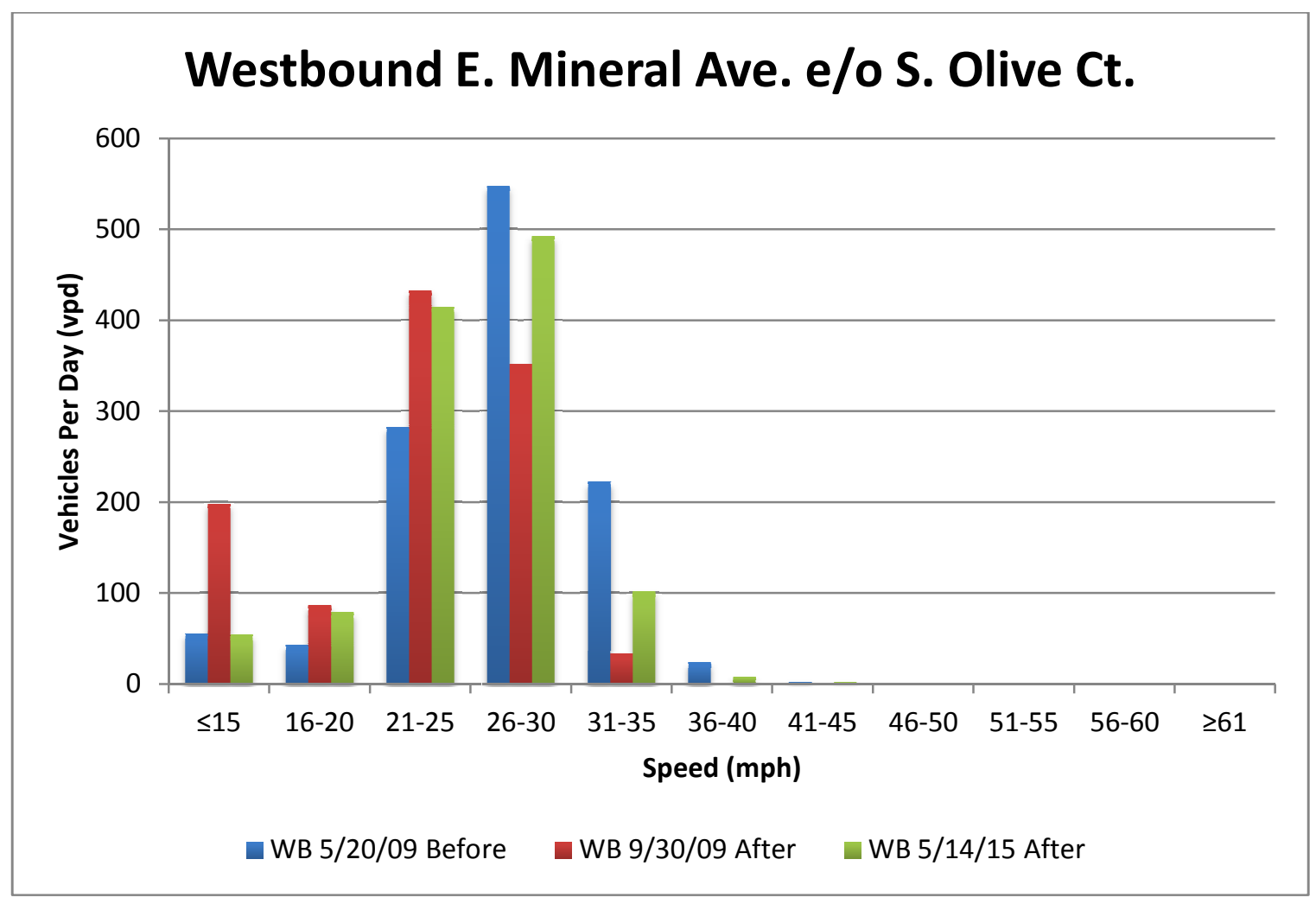

Figure 8: Westbound Mineral e/o Olive Speeds \& Volume

Tables 6 and 7 provide a summary of the crashes along E. Mineral Ave. Since 2008, the crashes have been property damage only. There have been no injuries and no fatalities. Most of the crashes occurred during the daytime.

\begin{tabular}{|r|l|l|l|}
\hline \multicolumn{1}{|l|}{ Date } & Type & Cross Street & Time \\
\hline $5 / 9 / 11$ & PDO & Pontiac Way & Daytime \\
\hline $4 / 12 / 11$ & PDO & Poplar Way & Daytime \\
\hline $8 / 21 / 07$ & PDO & Poplar Way & Daytime \\
\hline $8 / 15 / 07$ & PDO & Monaco St & Daytime \\
\hline $12 / 7 / 13$ & PDO & Magnolia Way & Daytime \\
\hline $1 / 12 / 09$ & PDO & Niagara Way & Daytime \\
\hline $10 / 31 / 08$ & PDO & Poplar Way & Nighttime \\
\hline $1 / 31 / 08$ & PDO & Niagara Way & Nighttime \\
\hline $1 / 31 / 08$ & PDO & Niagara Way & Daytime \\
\hline
\end{tabular}

Table 6: Fox Ridge-Mineral Crash Summary 


\begin{tabular}{|l|r|}
\hline Type & Crashes \\
\hline PDO & 11 \\
\hline Injury & 0 \\
\hline Fatality & 0 \\
\hline Total & 11 \\
\hline
\end{tabular}

Table 7: Fox Ridge-Mineral Crash Types

\section{E. Otero Avenue}

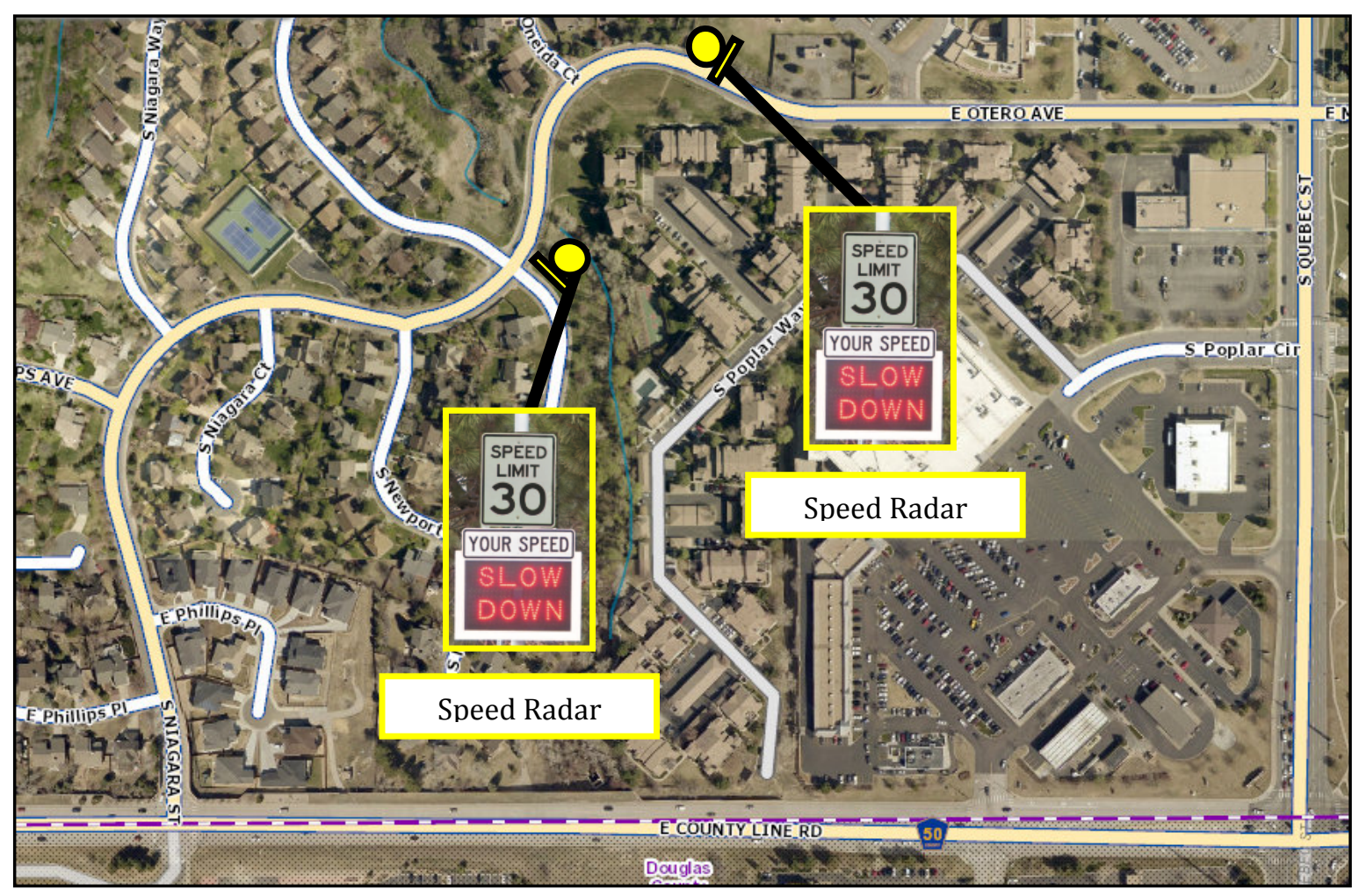

Figure 9: E. Otero Ave. NTMP

The before data were collected on February 12, 2009. The after data were collected immediately following the project implementation on March 11, 2009 and most recently on May 14, 2015. The results are summarized in Table 8 . 
Fox Ridge-Otero Ave.

\begin{tabular}{|l|c|c|c|c|c|c|}
\hline & $\begin{array}{c}\text { Volume } \\
\text { (ADT) }\end{array}$ & $\begin{array}{c}\text { 85th } \\
\text { Percentile }\end{array}$ & $\begin{array}{c}\text { Volume } \\
\text { (ADT) }\end{array}$ & $\begin{array}{c}\text { 85th } \\
\text { Percentile }\end{array}$ & $\begin{array}{c}\text { Volume } \\
\text { (ADT) }\end{array}$ & $\begin{array}{c}\text { 85th } \\
\text { Percentile }\end{array}$ \\
\cline { 2 - 7 } & \multicolumn{2}{|c|}{$2 / 12 / 09$} & Before & \multicolumn{2}{|c|}{$3 / 11 / 09$ After } & \multicolumn{2}{|c|}{$5 / 14 / 15$ After } \\
\hline EB & 878 & $30 \mathrm{MPH}$ & 1179 & $25 \mathrm{MPH}$ & 1089 & $28 \mathrm{MPH}$ \\
\hline WB & 729 & $29 \mathrm{MPH}$ & 912 & $33 \mathrm{MPH}$ & 1295 & $26 \mathrm{MPH}$ \\
\hline
\end{tabular}

Fox Ridge-Niagara St.

\begin{tabular}{|l|c|c|c|c|c|c|}
\hline & $\begin{array}{c}\text { Volume } \\
\text { (ADT) }\end{array}$ & $\begin{array}{c}\text { 85th } \\
\text { Percentile }\end{array}$ & $\begin{array}{c}\text { Volume } \\
\text { (ADT) }\end{array}$ & $\begin{array}{c}\text { 85th } \\
\text { Percentile }\end{array}$ & $\begin{array}{c}\text { Volume } \\
\text { (ADT) }\end{array}$ & $\begin{array}{c}\text { 85th } \\
\text { Percentile }\end{array}$ \\
\cline { 2 - 7 } & \multicolumn{2}{|c|}{$2 / 12 / 09$} & Before & \multicolumn{2}{|c|}{$3 / 11 / 09$ After } & \multicolumn{2}{|c|}{$5 / 14 / 15$ After } \\
\hline EB & 821 & $30 \mathrm{MPH}$ & 821 & $31 \mathrm{MPH}$ & 752 & $24 \mathrm{MPH}$ \\
\hline WB & 872 & $28 \mathrm{MPH}$ & 927 & $28 \mathrm{MPH}$ & 1595 & $29 \mathrm{MPH}$ \\
\hline
\end{tabular}

Table 8: Fox Ridge-Otero 85th Percentile Speeds

The data shows a drop in $85^{\text {th }}$ percentile speeds from February 2009 to May 2015 for both E. Otero Avenue and S. Niagara St. The volume for westbound S. Niagara Street increased from $872 \mathrm{vpd}$ to $1595 \mathrm{vpd}$. The volume supports the idea that this route is being used for cut-through traffic since the adjacent arterials are experiencing heavy traffic. Southbound Quebec Street traffic is using the Fox Ridge neighborhood to avoid the southbound right turn from Quebec St. to westbound E. County Line Road. Figures 10 through 13 show the speeds and volume for E. Otero Avenue and S. Niagara Street. 


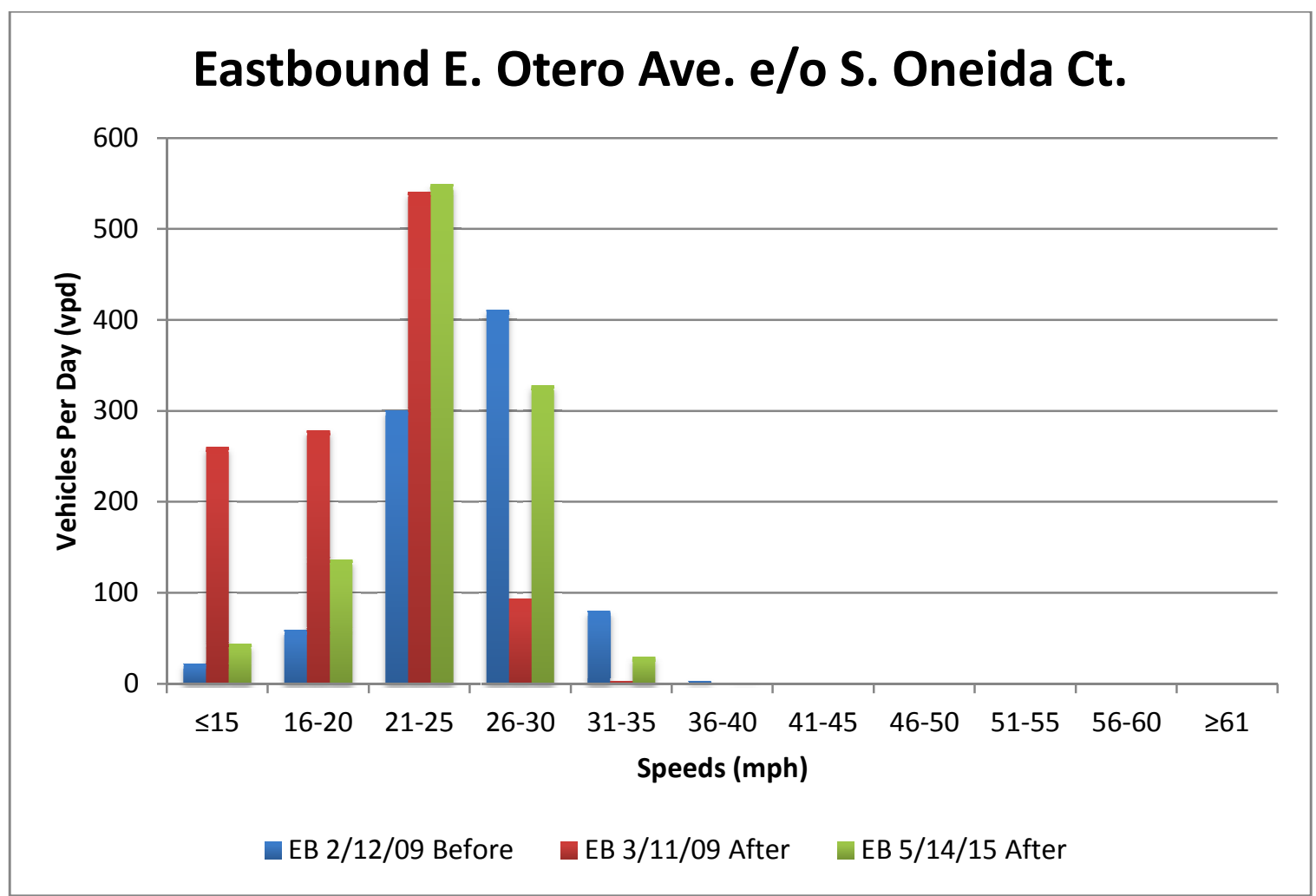

Figure 10: Eastbound Otero e/o Oneida Speeds \& Volume 


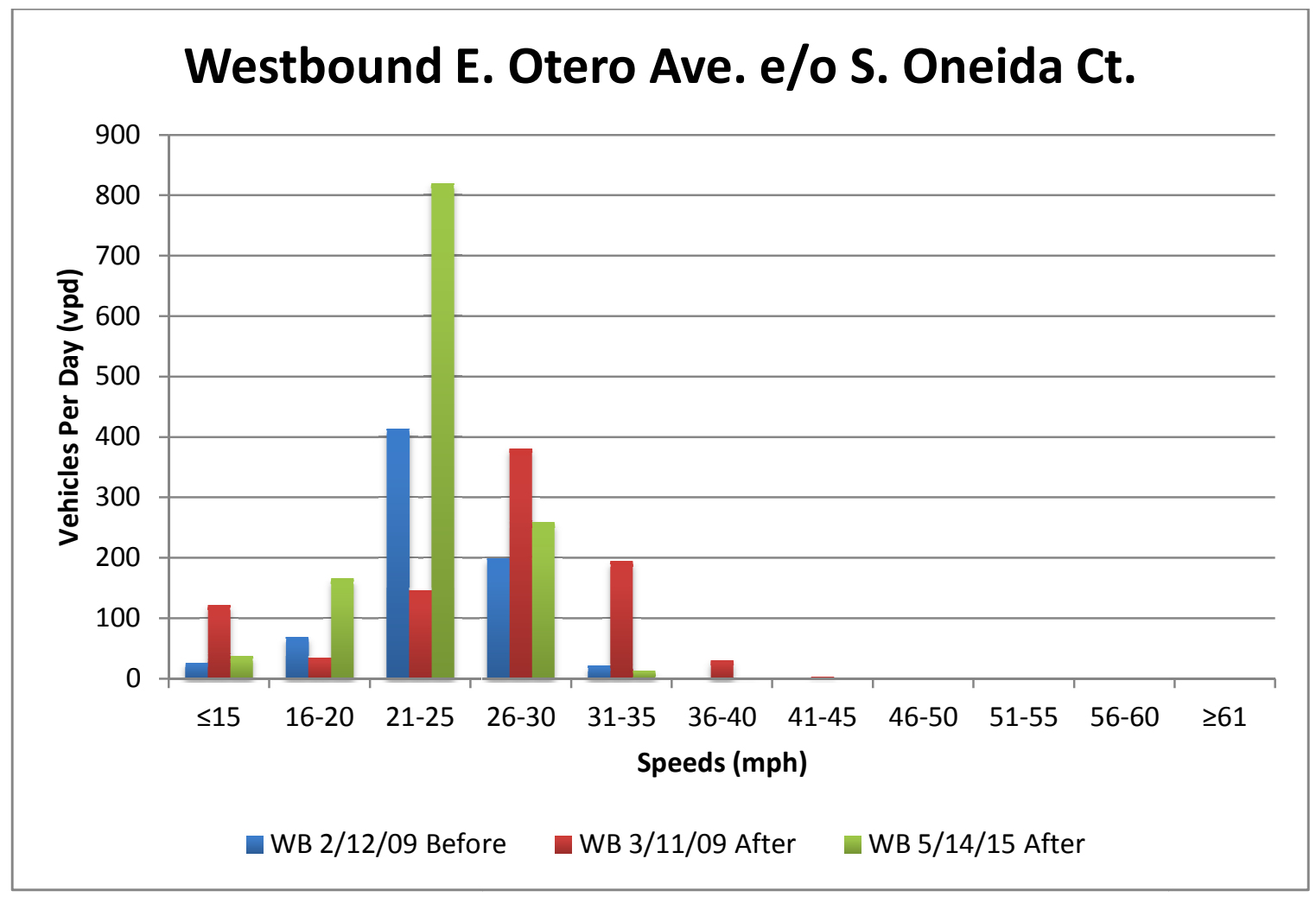

Figure 11: Westbound Otero e/o Oneida Speeds \& Volume 


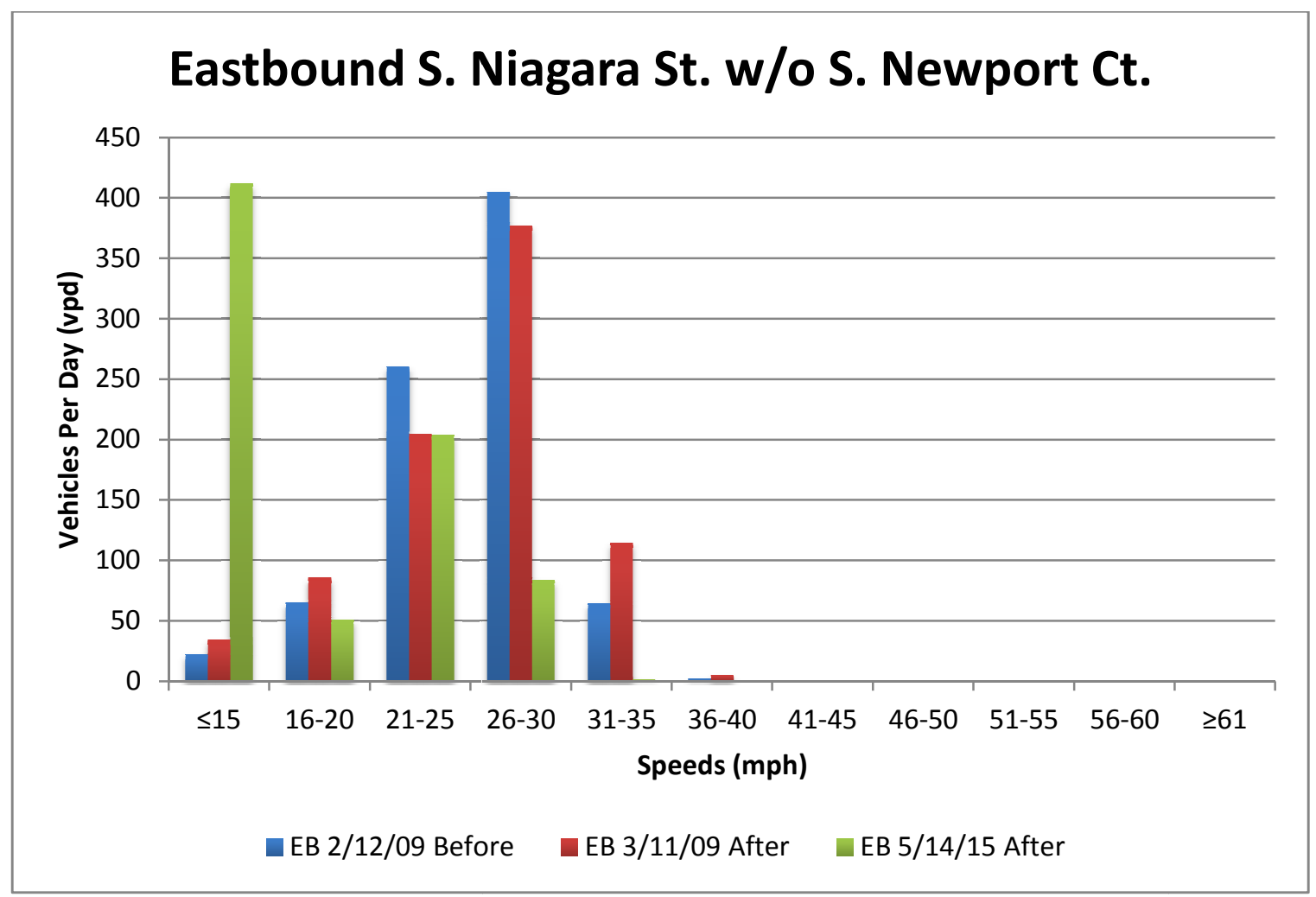

Figure 12: Eastbound Niagara w/o Newport Ct Speeds \& Volume 


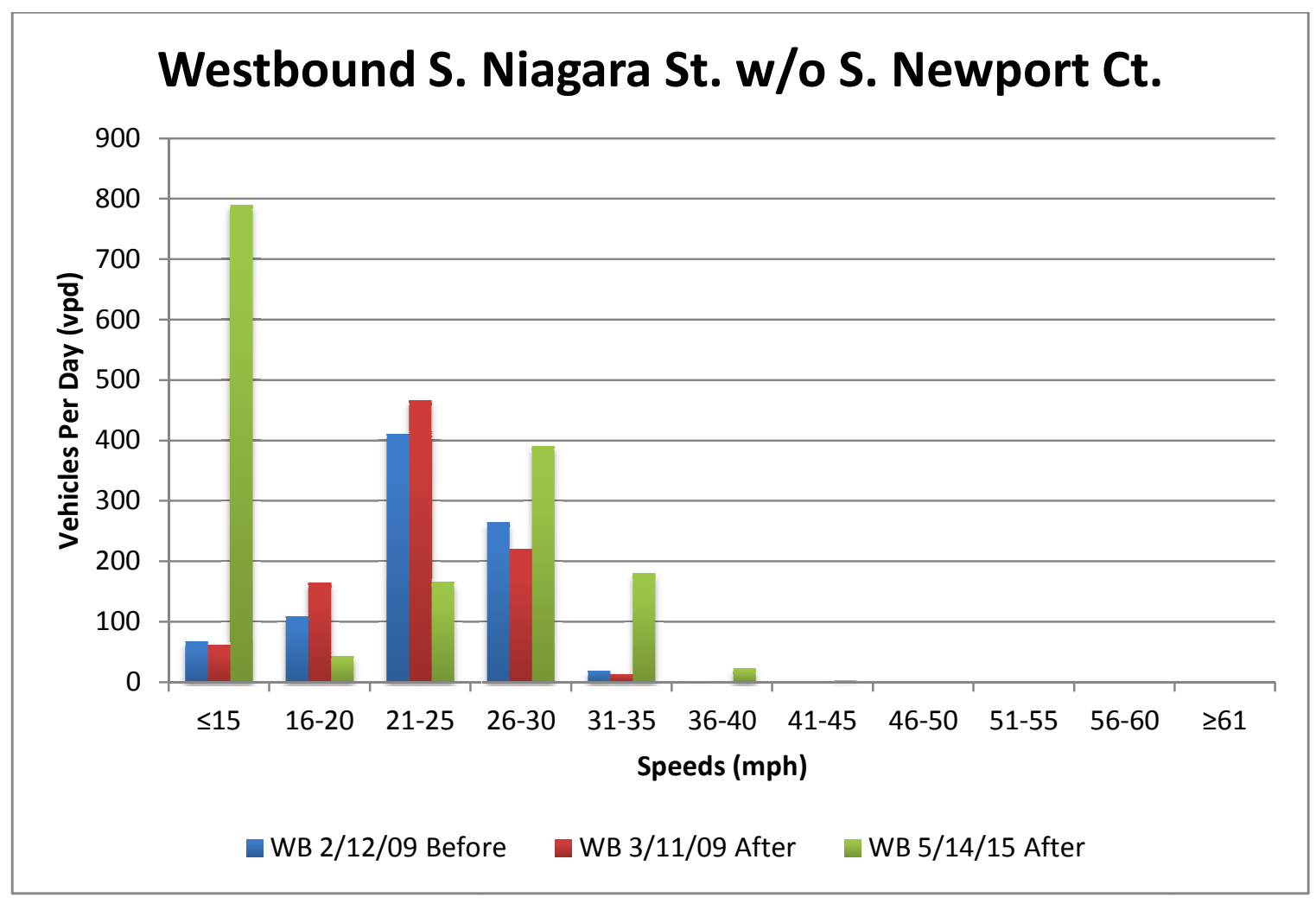

Figure 13: Westbound Niagara w/o Newport Speeds \& Volume

\begin{tabular}{|r|l|l|l|}
\hline \multicolumn{1}{|l|}{ Date } & Type & Cross Street & Time \\
\hline $12 / 25 / 09$ & PDO & Niagara Way & Nighttime \\
\hline $2 / 28 / 07$ & PDO & Phillips PI & Daytime \\
\hline $2 / 5 / 14$ & PDO & Newport Ct & Daytime \\
\hline $1 / 9 / 15$ & PDO & Newport Ct & Daytime \\
\hline $1 / 11 / 12$ & PDO & Newport Ct & Daytime \\
\hline $12 / 7 / 13$ & PDO & Newport Ct & Daytime \\
\hline $9 / 9 / 07$ & PDO & Newport Ct & Nighttime \\
\hline $12 / 8 / 07$ & PDO & Oneida Ct & Daytime \\
\hline $1 / 12 / 09$ & PDO & Oneida Ct & Daytime \\
\hline $12 / 6 / 13$ & PDO & Newport Ct & Daytime \\
\hline
\end{tabular}

Table 9: Fox Ridge-Otero Crash Summary

\begin{tabular}{|l|r|}
\hline Type & \multicolumn{2}{|l|}{ Crashes } \\
\hline PDO & 10 \\
\hline Injury & 0 \\
\hline Fatality & 0 \\
\hline Total & 10 \\
\hline
\end{tabular}

Table 10: Fox Ridge-Otero Crash Types 
Tables 9 and 10 provide a summary of the crashes along E. Otero Avenue. Since 2007, the crashes have been property damage only. There have been no injury and no fatality crashes. Most of the crashes occurred during the daytime.

\section{Park Borough - E. Dorado Avenue}

East Dorado Avenue is located on the east side of Centennial. The roadway is wide and residents had a concern for the speeding that was taking place. The speed limit on E. Dorado Avenue is 30 mph. The Park Borough neighborhood was selected for traffic mitigation. Through the NTMP policy procedure, three public meetings, and the toolbox of devices, the neighborhood selected electronic speed monitoring signs and lane narrowing, using centerline and bike lane pavement marking.

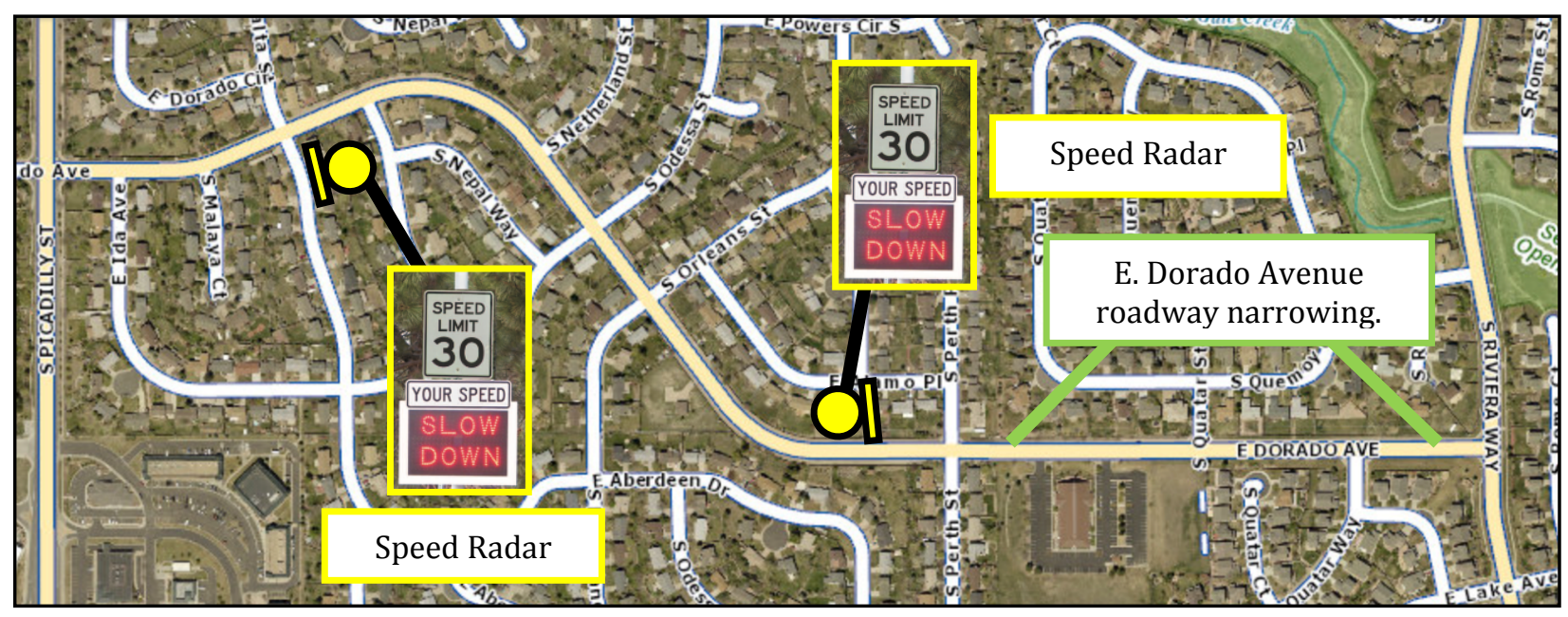

Figure 14: E. Dorado Ave. NTMP

The before study was conducted on April 20, 2011. The project was completed on May 5, 2011. An after study was conducted on May 11, 2011 and again most recently on April 15, 2015. The results are summarized below in Table 11. 
Dorado Ave. e/o Nepal St.

\begin{tabular}{|l|c|c|c|c|c|c|}
\hline & $\begin{array}{c}\text { Volume } \\
\text { (ADT) }\end{array}$ & $\begin{array}{c}\text { 85th } \\
\text { Percentile }\end{array}$ & $\begin{array}{c}\text { Volume } \\
\text { (ADT) }\end{array}$ & $\begin{array}{c}\text { 85th } \\
\text { Percentile }\end{array}$ & $\begin{array}{c}\text { Volume } \\
\text { (ADT) }\end{array}$ & $\begin{array}{c}\text { 85th } \\
\text { Percentile }\end{array}$ \\
\cline { 2 - 7 } & \multicolumn{2}{|c|}{$4 / 20 / 11$ Before } & \multicolumn{2}{|c|}{$5 / 11 / 11$ After } & \multicolumn{2}{|c|}{$4 / 15 / 15$ After } \\
\hline EB & 1147 & $34 \mathrm{MPH}$ & 1340 & $33 \mathrm{MPH}$ & 1312 & $37 \mathrm{MPH}$ \\
\hline WB & 1327 & $39 \mathrm{MPH}$ & 1274 & $38 \mathrm{MPH}$ & 1223 & $33 \mathrm{MPH}$ \\
\hline
\end{tabular}

Dorado Ave. w/o Perth St.

\begin{tabular}{|l|c|c|c|c|c|c|}
\hline & $\begin{array}{c}\text { Volume } \\
\text { (ADT) }\end{array}$ & $\begin{array}{c}\text { 85th } \\
\text { Percentile }\end{array}$ & $\begin{array}{c}\text { Volume } \\
\text { (ADT) }\end{array}$ & $\begin{array}{c}\text { 85th } \\
\text { Percentile }\end{array}$ & $\begin{array}{c}\text { Volume } \\
\text { (ADT) }\end{array}$ & $\begin{array}{c}\text { 85th } \\
\text { Percentile }\end{array}$ \\
\cline { 2 - 7 } & \multicolumn{2}{|c|}{$4 / 20 / 11$ Before } & \multicolumn{2}{|c|}{$5 / 11 / 11$ After } & \multicolumn{2}{|c|}{$4 / 15 / 15$ After } \\
\hline EB & 969 & $34 \mathrm{MPH}$ & 987 & $40 \mathrm{MPH}$ & 993 & $36 \mathrm{MPH}$ \\
\hline WB & 876 & $37 \mathrm{MPH}$ & 950 & $36 \mathrm{MPH}$ & 917 & $35 \mathrm{MPH}$ \\
\hline
\end{tabular}

Table 11: Park Borough-Dorado 85th Percentile Speeds

The Dorado Avenue data shows the least benefit from traffic calming. The speeds are almost unchanged from the before data and traffic volumes have remained steady. This supports the idea that on a long straight roadway, permanent roadway narrowing with neckdowns may have been a better option rather than painted stripes. During field visits, it was observed that vehicles were driving in the bike lanes to create greater space between the oncoming vehicles and them. This defeats the purpose of slowing down vehicles with roadway narrowing.

Figures 15 through 18 show the speeds and volume for E. Dorado Avenue. 


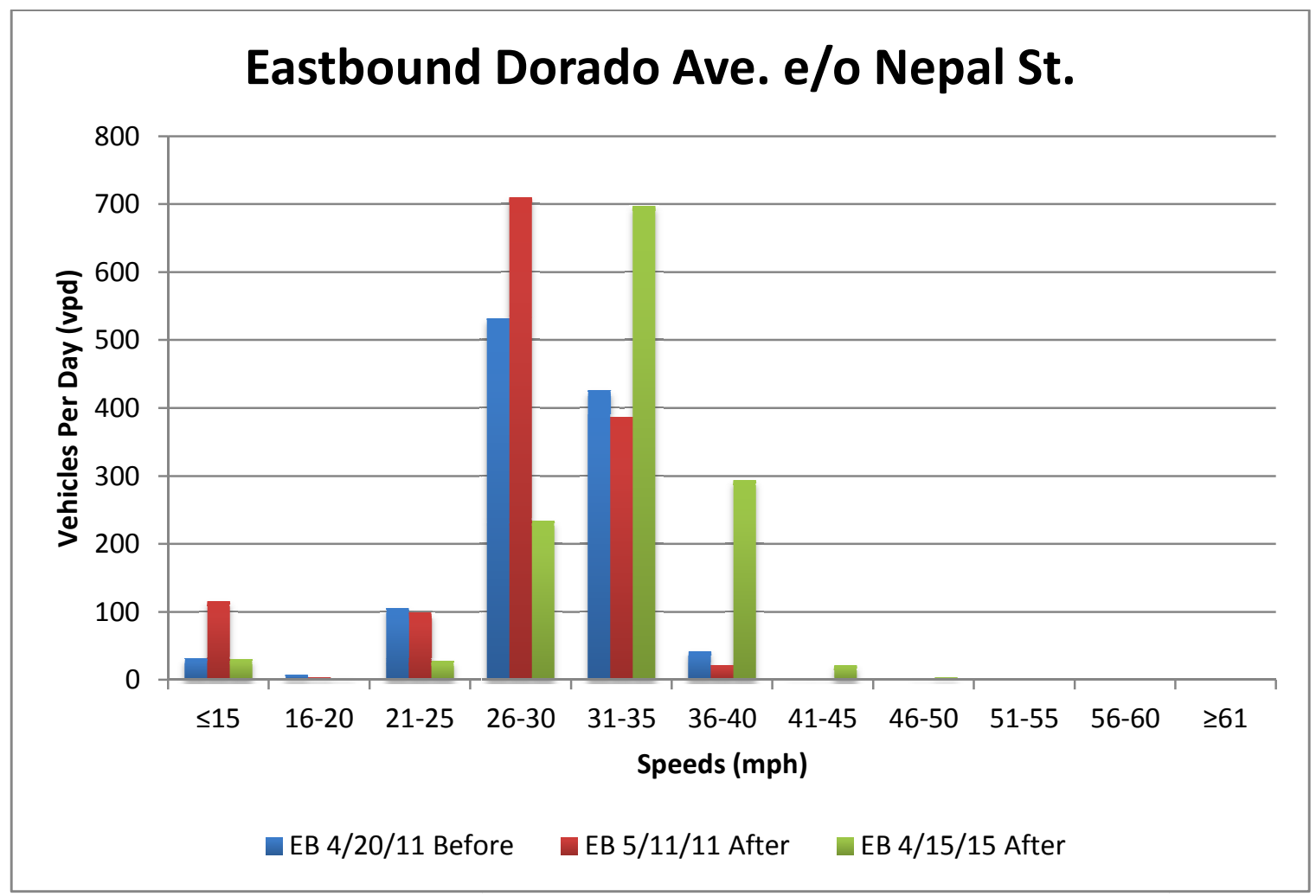

Figure 15: Eastbound Dorado e/o Nepal St. Speeds \& Volumes 


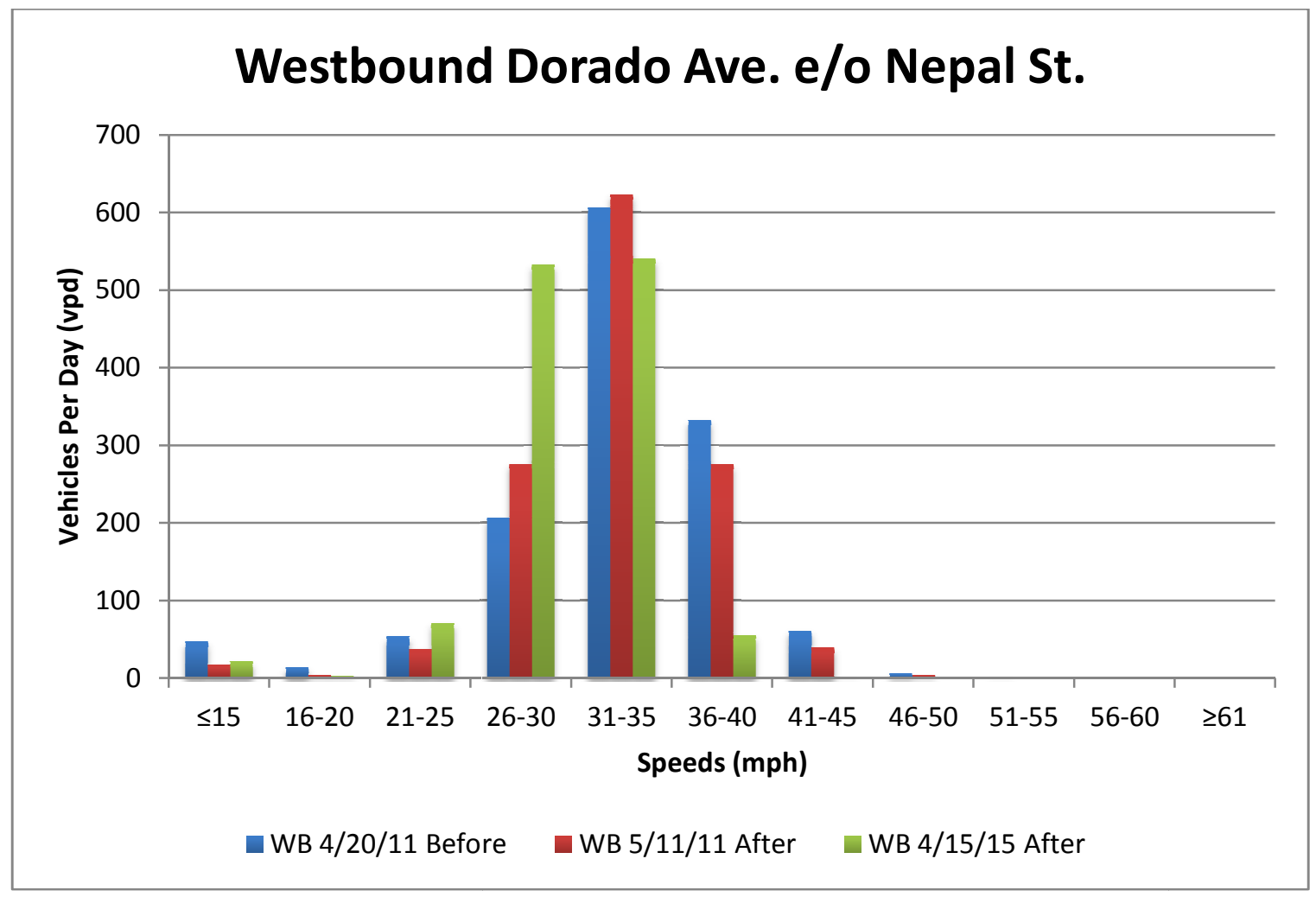

Figure 16: Westbound Dorado e/o Nepal St. Speeds \& Volume 


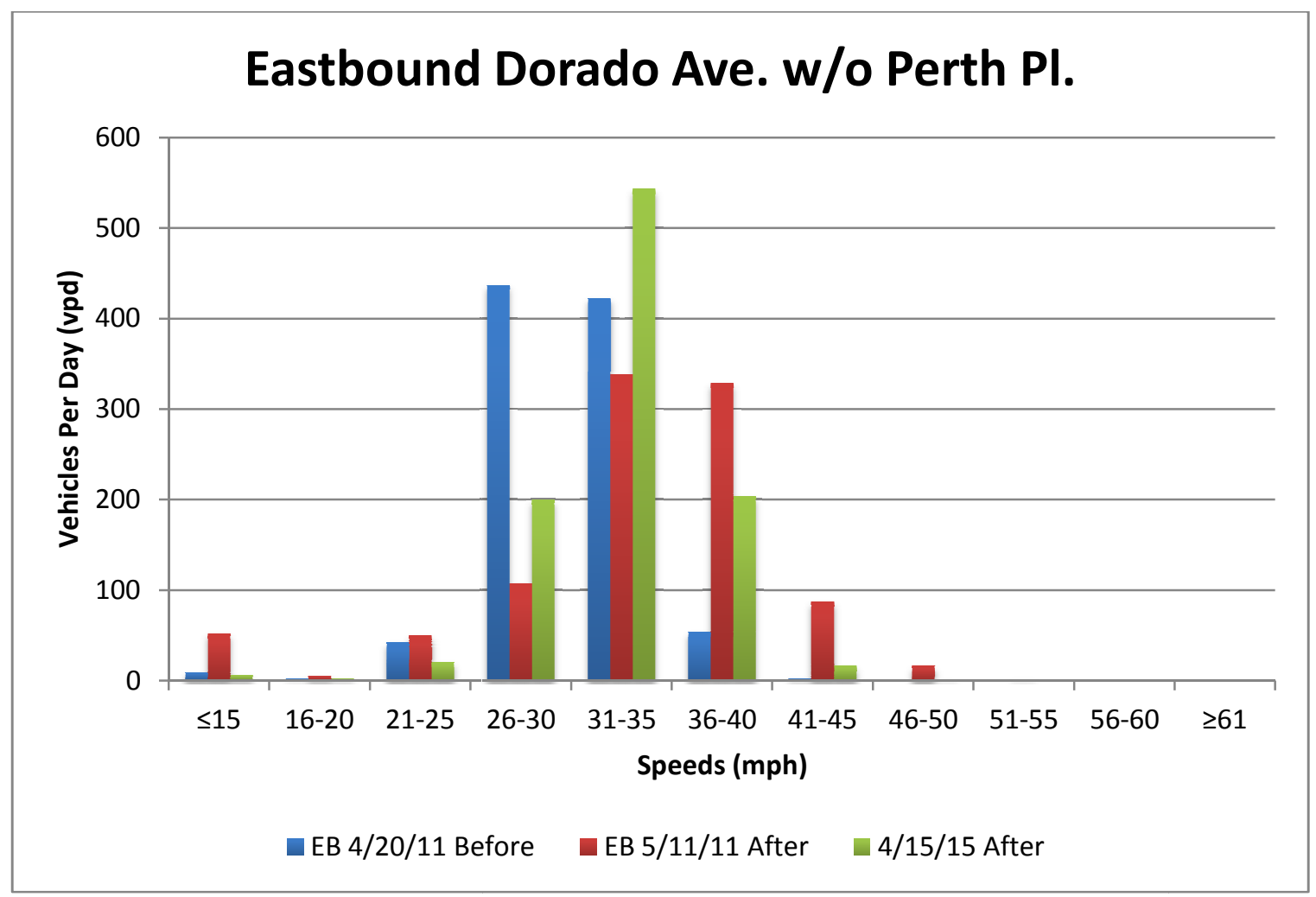

Figure 17: Eastbound Dorado w/o Perth PI. Speeds \& Volume 


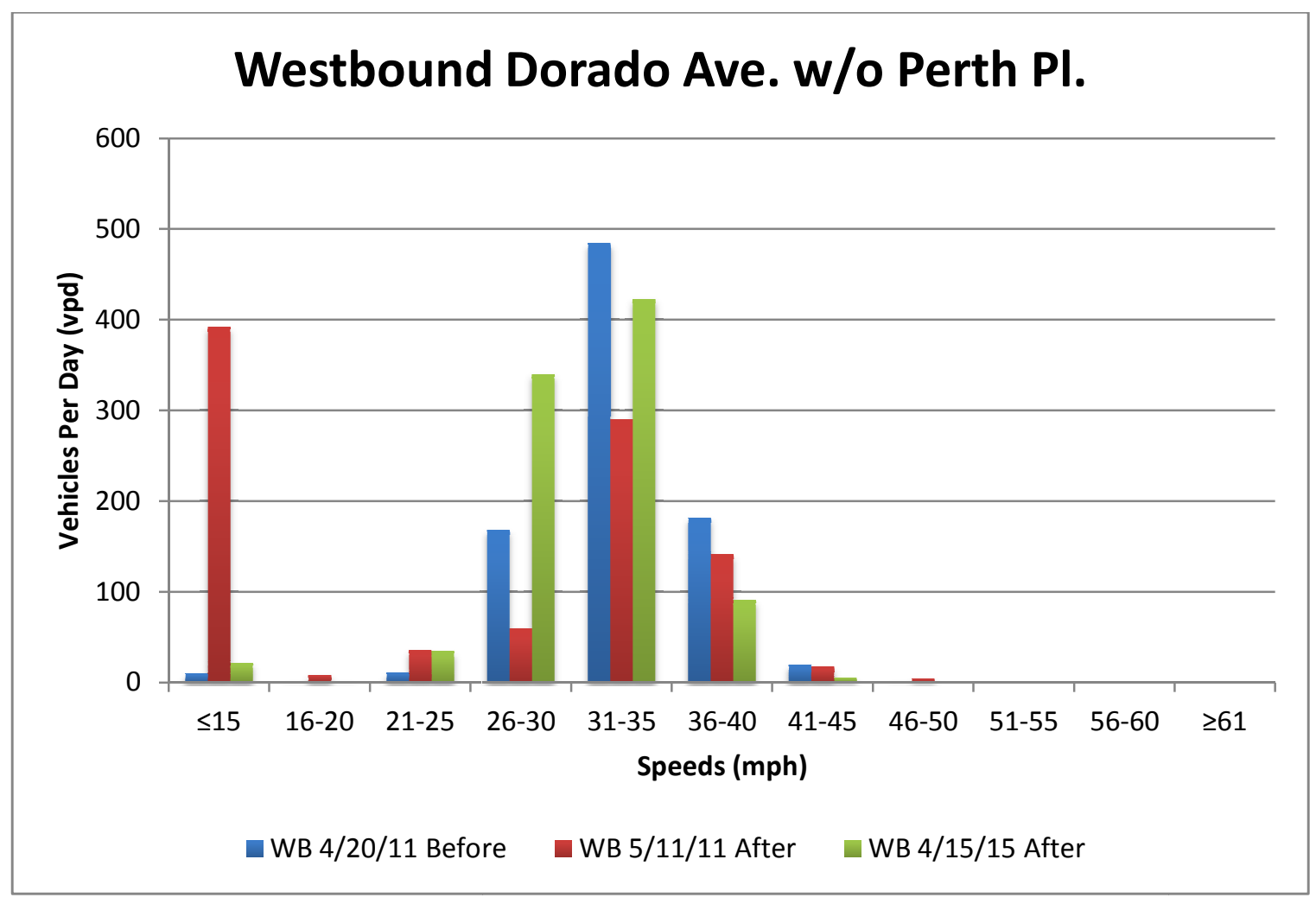

Figure 18: Westbound Dorado w/o Perth PI. Speeds \& Volume

The results show that after an initial drop in $85^{\text {th }}$ percentile speeds immediately following the project implementation, but an increase.

\begin{tabular}{|r|l|l|l|}
\hline \multicolumn{1}{|l|}{ Date } & Type & Cross Street & Time \\
\hline $2 / 11 / 07$ & PDO & Nepal St & Nighttime \\
\hline $8 / 14 / 07$ & PDO & Perth PI & Daytime \\
\hline $7 / 9 / 08$ & Injury & Orleans St & Daytime \\
\hline $10 / 29 / 09$ & PDO & Orleans St & Daytime \\
\hline $9 / 7 / 10$ & PDO & Ida Ave & Nighttime \\
\hline $10 / 31 / 11$ & PDO & Malaya Ct & Daytime \\
\hline $8 / 13 / 12$ & PDO & Nepal St & Daytime \\
\hline $1 / 14 / 13$ & PDO & Nepal St & Daytime \\
\hline $2 / 12 / 13$ & PDO & Orleans St & Daytime \\
\hline $2 / 21 / 13$ & PDO & Perth PI & Nighttime \\
\hline $1 / 7 / 14$ & PDO & Orleans St & Nighttime \\
\hline $5 / 6 / 14$ & PDO & Orleans St & Daytime \\
\hline $12 / 29 / 14$ & PDO & Nepal St & Daytime \\
\hline
\end{tabular}

Table 12: Park Borough Crash Summary 


\begin{tabular}{|l|r|}
\hline Type & Crashes \\
\hline PDO & 12 \\
\hline Injury & 1 \\
\hline Fatality & 0 \\
\hline Total & 13 \\
\hline
\end{tabular}

Table 13: Park Borough Crash Types

Tables 12 and 13 show a summary of the crash types. There were a total of 13 crashes along E. Dorado Avenue from 2007 through May 2015. Twelve of those crashes were property damage only and one was an injury crash.

\subsection{Highlands 460 - E. Otero Avenue and S. Adams Street}

The Highlands 460 neighborhood was the number one ranked NTMP applicant in 2013. South Adams Street and E. Otero Avenue form a cut-through route that allows residents from the southern side of the city to by-pass the often-congested intersection at S. University Boulevard and E. Dry Creek Road when trying to access the Denver Technological Center.

No homes face either street but residents had numerous concerns about speeding vehicles losing control and destroying their fences. Additionally, Arapaho Park is located nearby which attracts recreational activities. The combination of high speeds and the presence of pedestrians led the neighborhood and City to develop a traffic mitigation plan that combined speed monitoring signs with new curve warning signs. The locations of the speed monitoring signs are shown in Figure 19. 


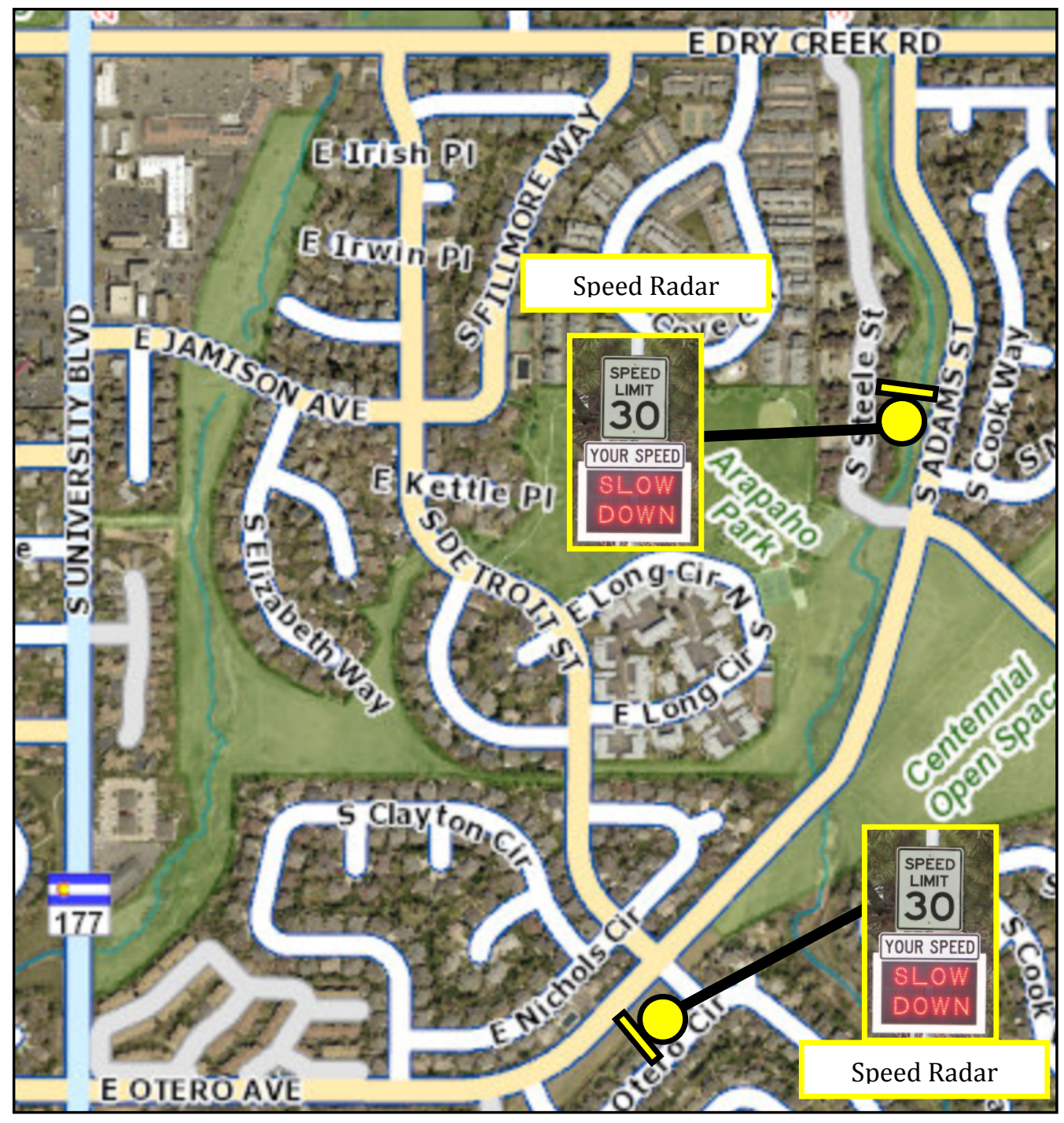

Figure 19: Highlands 460 NTMP

The before data were collected on February 6, 2013. The project was implemented in Spring 2014. The after data were collected on April 15, 2015. A summary of the $85^{\text {th }}$ percentile speeds is shown in Table 14. 
Highlands 460 Adams n/o Madison Cir.

\begin{tabular}{|c|c|c|c|c|}
\hline & $\begin{array}{l}\text { Volume } \\
\text { (ADT) }\end{array}$ & $\begin{array}{c}\text { 85th } \\
\text { Percentile }\end{array}$ & $\begin{array}{l}\text { Volume } \\
\text { (ADT) }\end{array}$ & $\begin{array}{c}\text { 85th } \\
\text { Percentile }\end{array}$ \\
\hline & \multicolumn{2}{|c|}{ 2/6/13 Before } & \multicolumn{2}{|c|}{ 4/15/15 After } \\
\hline NB & 1288 & $40 \mathrm{MPH}$ & 1440 & $41 \mathrm{MPH}$ \\
\hline SB & 1296 & $39 \mathrm{MPH}$ & 1424 & $28 \mathrm{MPH}$ \\
\hline
\end{tabular}

Highlands 460 Otero e/o Phillips Dr.

\begin{tabular}{|c|c|c|c|c|}
\hline & $\begin{array}{l}\text { Volume } \\
\text { (ADT) }\end{array}$ & $\begin{array}{c}\text { 85th } \\
\text { Percentile }\end{array}$ & $\begin{array}{c}\text { Volume } \\
\text { (ADT) }\end{array}$ & $\begin{array}{c}\text { 85th } \\
\text { Percentile }\end{array}$ \\
\hline & \multicolumn{2}{|c|}{ 2/6/13 Before } & \multicolumn{2}{|c|}{ 4/15/15 After } \\
\hline EB & 1081 & $45 \mathrm{MPH}$ & 1293 & $36 \mathrm{MPH}$ \\
\hline WB & 1067 & $41 \mathrm{MPH}$ & 1285 & $33 \mathrm{MPH}$ \\
\hline
\end{tabular}

Table 14: Highlands 460 85th Percentile Speeds

The Highlands 460 NTMP is the newest project to be implemented. Not surprisingly, it also has the largest drop in $85^{\text {th }}$ percentile speeds. The chi-square test shows a value of $5.03 \mathrm{E}-48$ for the speed distributions, thus below the value of 0.05 , making the change statistically significant. Figures 20 through 23 show speeds and volumes along S. Adams Street and E. Otero Avenue.

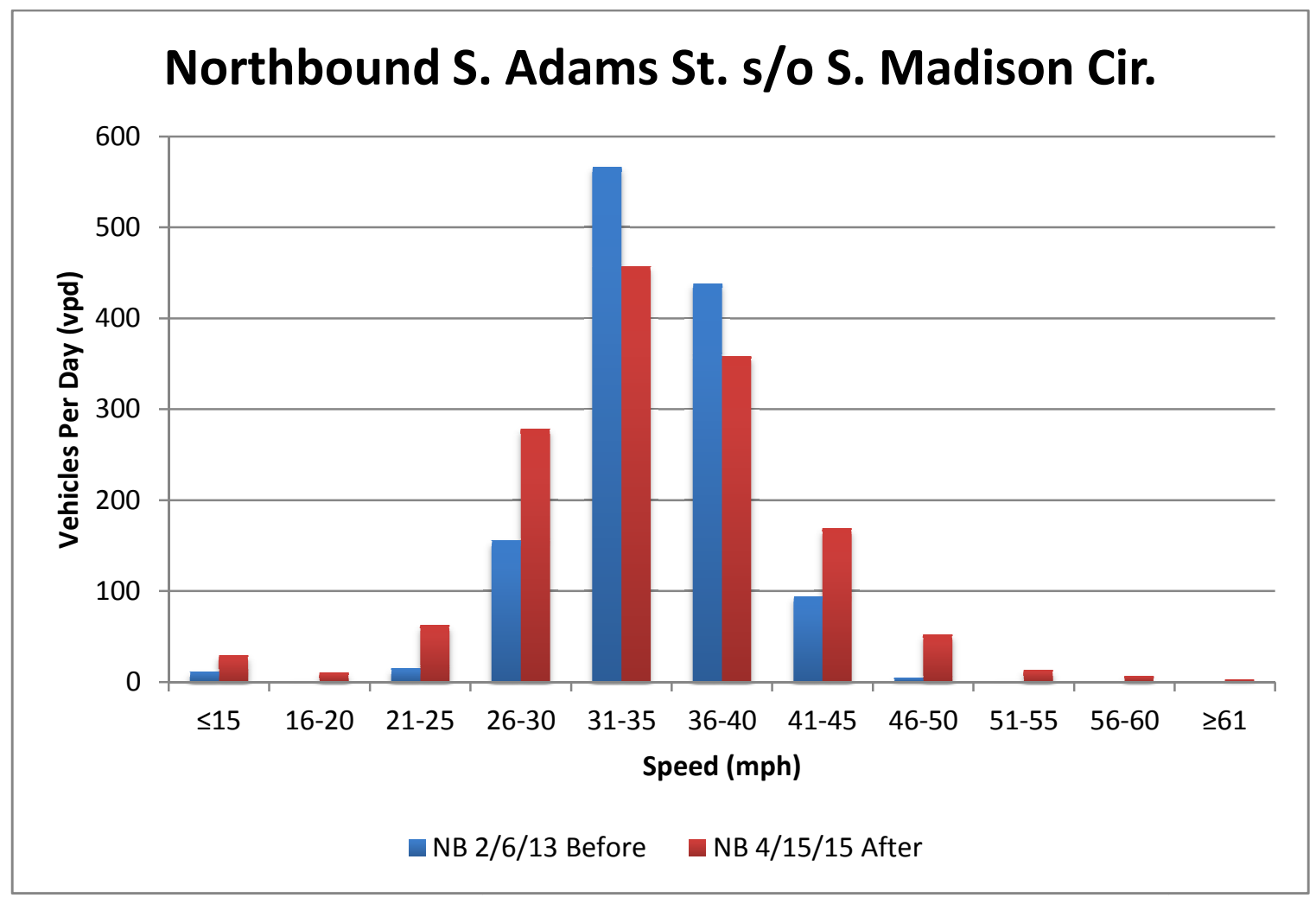

Figure 20: Northbound Adams s/o Madison Cir. Speeds \& Volume 


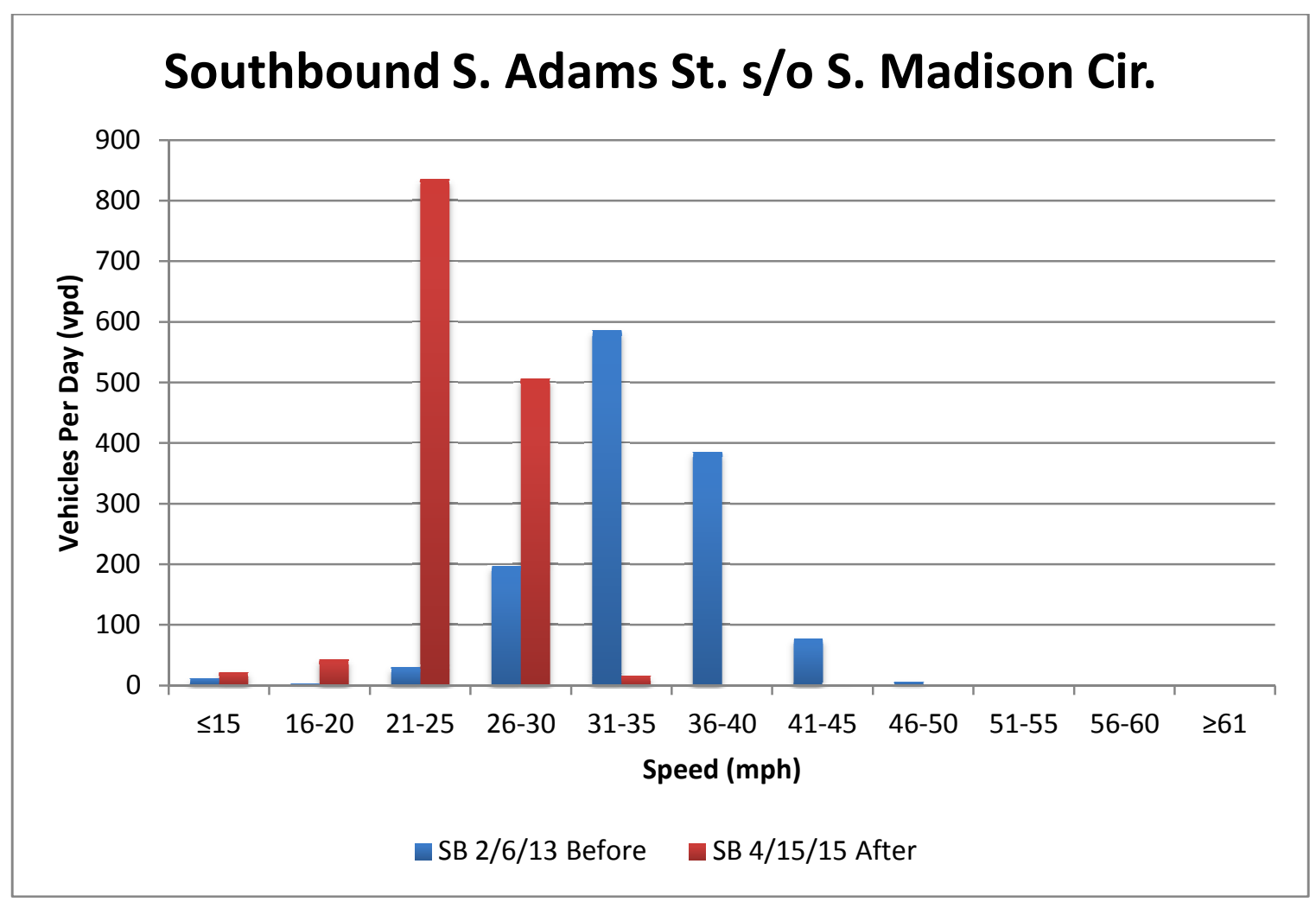

Figure 21: Southbound Adams s/o Madison Cir. Speeds \& Volume 


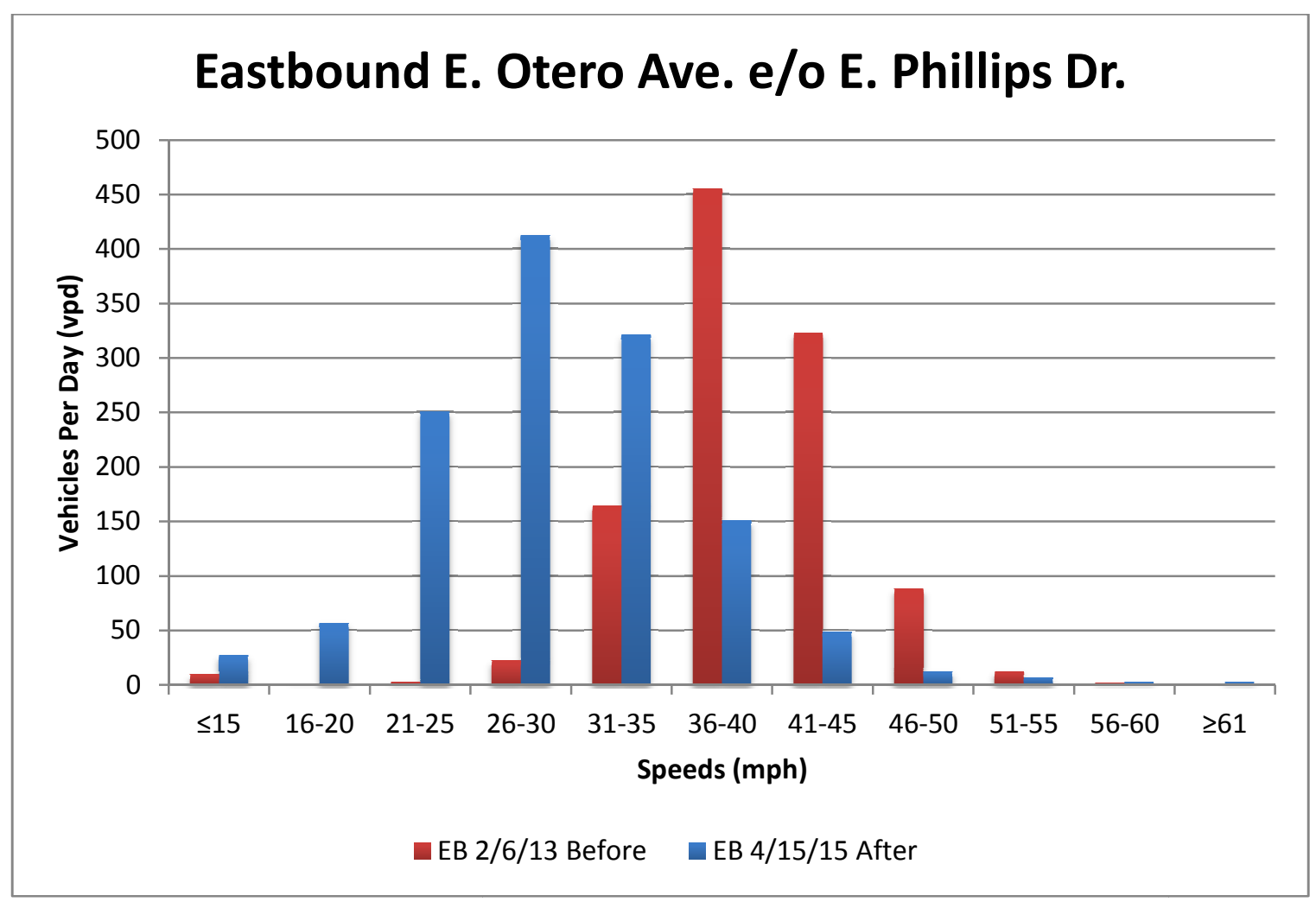

Figure 22: Eastbound Otero e/o Phillips Dr. Speeds \& Volume 


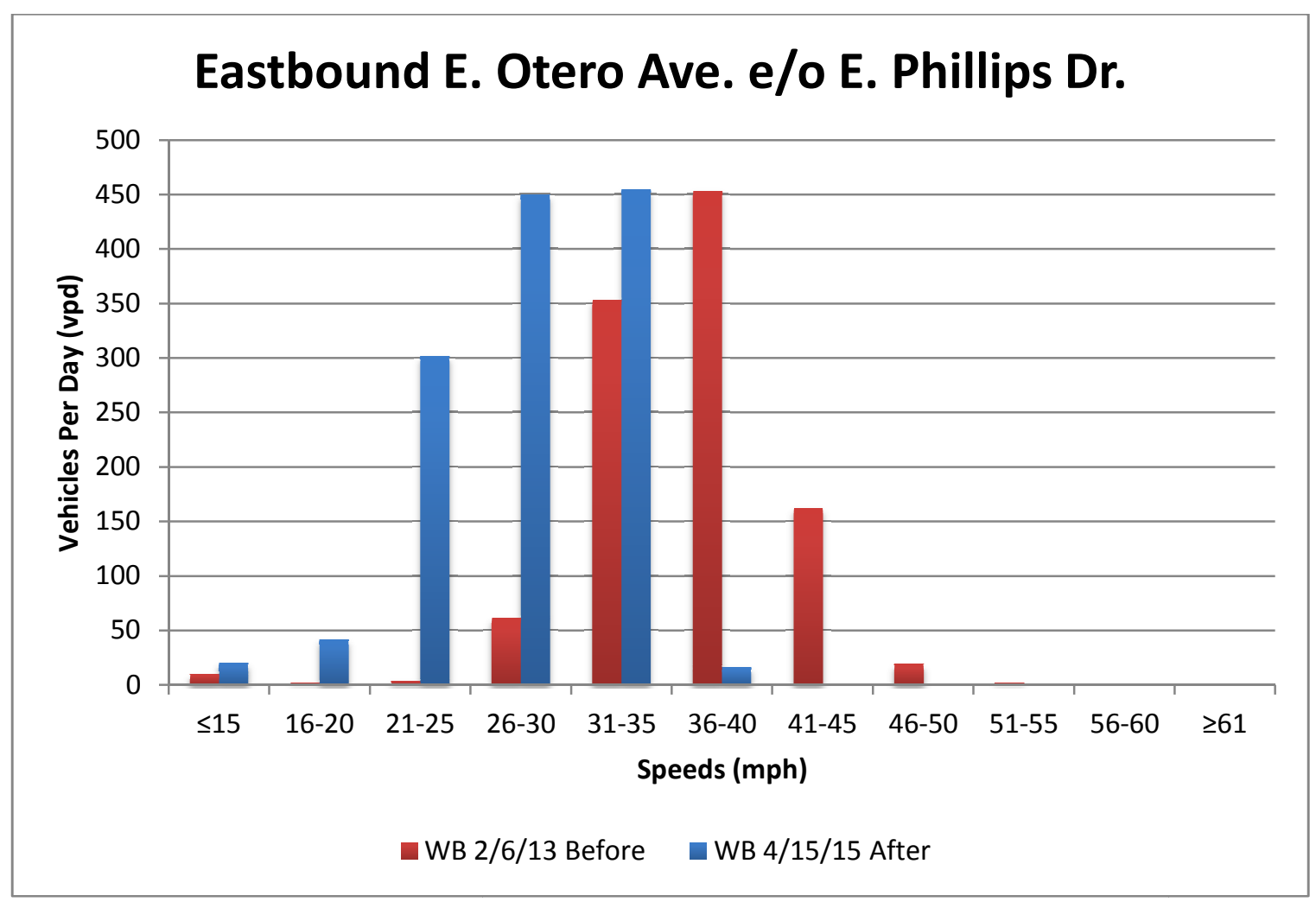

Figure 23: Eastbound Otero Ave. e/o Phillips Dr. Speeds \& Volume 
A summary of the crashes from 2007 through May 2015 is shown in Figures 15 and 16. A total of 21 crashes occurred during this time period during both daytime and nighttime. Two of the crashes were injury related while the remaining 19 crashes were property damage only.

\begin{tabular}{|r|l|l|l|}
\hline \multicolumn{1}{|l|}{ Date } & Type & Cross Street & Time \\
\hline $1 / 31 / 07$ & PDO & Phillips Dr & Nighttime \\
\hline $1 / 31 / 08$ & PDO & Clayton Cir & Nighttime \\
\hline $11 / 12 / 08$ & Injury & Clayton Cir & Nighttime \\
\hline $12 / 14 / 08$ & PDO & Madison Cir & Daytime \\
\hline $1 / 12 / 09$ & PDO & Phillips Dr & Daytime \\
\hline $2 / 14 / 09$ & PDO & Clayton Cir & Nighttime \\
\hline $2 / 28 / 09$ & PDO & Clayton Cir & Nighttime \\
\hline $4 / 27 / 09$ & PDO & Phillips Dr & Nighttime \\
\hline $1 / 7 / 10$ & PDO & Phillips Dr & Daytime \\
\hline $9 / 13 / 10$ & PDO & Columbine Ct & Nighttime \\
\hline $11 / 17 / 10$ & Injury & Fillmore Way & Nighttime \\
\hline $11 / 26 / 10$ & PDO & Clayton Cir & Daytime \\
\hline $12 / 7 / 10$ & PDO & Madison Cir & Daytime \\
\hline $5 / 9 / 11$ & PDO & Phillips Dr & Daytime \\
\hline $12 / 6 / 11$ & PDO & Madison Cir & Daytime \\
\hline $6 / 11 / 12$ & PDO & Nichols Cir & Daytime \\
\hline $2 / 26 / 13$ & PDO & Madison Cir & Daytime \\
\hline $4 / 15 / 14$ & PDO & Madison Cir & Daytime \\
\hline $9 / 14 / 14$ & PDO & Columbine Ct & Daytime \\
\hline $2 / 9 / 15$ & PDO & Milwaukee St & Daytime \\
\hline $4 / 28 / 15$ & PDO & Phillips Dr & Daytime \\
\hline
\end{tabular}

Table 15: Highlands 460 Crash Summary

\begin{tabular}{|l|r|}
\hline Type & \multicolumn{2}{|c|}{ Crashes } \\
\hline PDO & 19 \\
\hline Injury & 2 \\
\hline Fatality & 0 \\
\hline Total & 21 \\
\hline
\end{tabular}

Table 16: Highlands 460 Crash Types 


\section{Cut-through Volume Study}

The Centennial NTMP defines the minimum threshold for cut-through traffic consideration in the program to be 20 percent of the total directional traffic. Highlands 460 had concerns during the original 2013 application about cut-through traffic. Some data exist relating to an attempt at a before-study during the NTMP application ranking, but no reliable study was conducted at that time.

The cut-through study was conducted on Wednesday May 12, 2015 during the A.M. peak time period 7:30 A.M. to 8:30 A.M. which is the same time as the original attempts at cut-through data collection in 2013. This time period was chosen because of Highland 460 residents' concerns that Highland Ranch residents were using the E. Otero Avenue/S. Adams Street network to bypass the congested S. University Boulevard and E. Dry Creek Road intersection in the morning to access the Denver Technological Center. The shortcut consists of two right turns:

one from S. University Boulevard onto E. Otero Avenue, and a second one from S. Adams Street right onto E. Dry Creek Road. The P.M. peak pattern is the opposite but creates two signalized left turns instead of two right turns, which may deter drivers.

The cut-through data collection was performed using license plate number matching. Data were collected at two locations in Highlands 460:

1. Entering traffic at the entrance to the neighborhood on E. Otero Avenue east of $\mathrm{S}$. University Boulevard.

2. Exiting traffic at the neighborhood exit on S. Adams St. south of E. Dry Creek Road.

The travel time to traverse the neighborhood was estimated by trial runs at approximately 3 minutes. To be conservative, the actual travel times counted as cut-through included travel times up to 4 minutes to account for vehicles traveling below the speed limit or stopped longer at the all-way stop controlled intersection at S. Monroe Way.

A total of 103 vehicles entered the neighborhood during the study time, while 24 of the vehicles were recorded exiting the neighborhood at the other end. This results in $23 \%$ cut-through volume, which is greater than the $20 \%$ needed to meet requirements for a cut-through problem. 
Therefore the project would need modifications to determine the best possible option(s) to reduce the cut-through volume. 


\subsection{CONCLUSIONS}

\subsection{Challenges}

\section{Intersection Magic}

The crash data is provided by the ACSO. The ACSO officers must report the data for each crash based on street block numbers. Since reporting the crash data in terms of block numbers can be confusing to those requesting the data, the data must be translated from block numbers to actual street names. The Centennial crash database has each street name associated with a block number. Therefore, the monthly crash data has to undergo an import-export-import process beginning with a comma separated value file sent by the ACSO. This data set is imported into Intersection Magic, then exported as an Excel file to merge with the Centennial streets manager database in Microsoft Access. Finally, that file is imported back into Intersection Magic. The entire process creates the potential for data loss and corruption. Misspellings in any street name on behalf of the ACSO will result in that record being omitted from queries.

When analyzing an NTMP corridor, an intersection zone filter exists to identify which crashes are related to an intersection. However, this filter will omit intersection-related crashes that fall outside of the zone. Removing the filter will include all crashes, both intersection related and non-intersection related, but must be within 100 feet of the nearest intersection. It is possible to extend the zone in the program settings, but the zone size needed to capture crashes between cross streets varies. There is concern that some overlap as well as some data loss may occur.

With Centennial being a newer city, crash data is only available beginning in 2007. It is difficult to form conclusions on any crash patterns. Furthermore, the exact implementation of each NTMP project is unclear. Therefore it is difficult to make a conclusion on changes in crashes before and after a project.

\section{Speed Data}

A contractor collected the speed data sets. The data sets were delivered as a PDF document only. The volumes are reported in traffic bins. The data is not detailed enough for each individual vehicle that passed through the study area. For example, if 300 vehicles were logged in the 26-30 mph speed bin, the data is not specific enough to list where in that range each vehicle was. 
Although unlikely, it could have been that all 300 vehicles were traveling at $26 \mathrm{mph}$ or all 300 vehicles at $30 \mathrm{mph}$.

\subsection{Recommendations}

The Centennial NTMP should continue to focus on the three E's: education, enforcement, and engineering.

\section{Education}

Educate the residents and City staff on the NTMP policy. Often, residents are directed to the NTMP over unrelated neighborhood concerns. The result is that residents have to wait for the NTMP evaluation just to learn that their neighborhood did not even meet the minimum requirements. Many times, their concerns can and should be addressed outside of the NTMP. Those residents whose neighborhoods do make good candidates for the NTMP should follow the correct procedure. Centennial NTMP requires neighbors to put forth an effort and collect proof of support from neighbors. Recently, this step has been omitted.

Residents also make the mistake of confusing the NTMP as solely a program to fund what the applicant has in mind for traffic mitigation. The NTMP is intended to be a collaborative effort between residents and City engineers using the NTMP policy as a guide to come up with the best solution. Additionally, residents should think long-term when evaluating which NTMP toolbox items would work best for the neighborhoods. An example is the speed monitoring sign, which has proven popular among NTMP neighborhoods. There is a belief that the speed monitoring signs also have enforcement cameras and therefore that deterrent helps in driver speed compliance. However, drivers quickly will realize this is not the case and their driving habits will adjust and likely lead to higher speeds. Residents must be open to the idea of ideas such as roadway narrowing. The narrowing will be a permanent physical change to the roadway and will not lose its effectiveness as quickly as the speed monitoring signs.

Lessons from the NTMPs of other cities should be used to further educate residents. Lee's Summit, Missouri residents can work with law enforcement to log vehicle speeds using a speed radar gun. This helps residents understand the different between perceived vehicle speeds and actual speeds. Centennial should consider involving the ACSO more in the NTMP and follow 
the example of Scottsdale, Arizona. The Scottsdale NTMP applicants are required to work with police officers as part of the program. They log vehicle speeds and make contact with violators via mail in the form of warnings, but not fines.

\section{Enforcement}

Residents need to understand that police officers cannot always be present in residential neighborhoods for traffic enforcement. It is a difficult situation because residents of the neighborhood are often the ones committing the speeding violations. Additionally, the ACSO does not generate sufficient revenue in an hour from speeding fines to justify the cost of the officer to patrol the roadway for that hour. Law enforcement should be present during the initial implementation of any new NTMP project to help educate all users of the roadway and to adjust to any modifications.

\section{Engineering}

The Centennial NTMP is periodically revised and the following are some ideas for improvement in regards to engineering. West Jordan, Utah uses a test installation program prior to implementing permanent modifications. The tests run between 4 and 12 months. Modifications are made during this trial period if engineers and residents are not satisfied and will continue to be made until all parties agree on the test set up. Once a satisfactory trial period has passed, the neighborhood goes to the city council for final approval and permanent construction. Centennial has a history of removing speed humps due to noise and perceived rattling of homes. Using test installations (speed cushions) would allow neighbors to see the impact of such a traffic calming tool without committing to it permanently.

Evaluate the problematic toolbox items. While speed humps are popular with residents because they do work at reducing vehicle speeds, maintenance crews find them challenging. The humps are difficult to plow over during snow events. The toolbox item that closes a street requires a lot of political power to make happen. Furthermore, emergency services would lose access if a roadway were closed and increase response time, which is undesirable. The actual chance that these negative impacts of the toolbox items would change is very unlikely. Centennial engineers 
need to evaluate these toolbox items and determine if they should even be included as options in the NTMP.

\subsection{Future Research}

The main motivation for future research is because residents respond positively to local examples of successful traffic mitigation. While the examples from Lee's Summit, West Jordan, and Scottsdale provide great ideas, the existing Centennial NTMP projects will influence the direction of future projects. The success of the projects should be evaluated by conducting an after study that includes the data collection presented in this report and survey of resident satisfaction.

Future research could also look at the opposite of mainly positive expectations from an NTMP implementation. Are there any negative impacts? Residents have asked what the impact to their property value will be a result of NTMP projects. A neighborhood street with lower traffic speeds sounds appealing, but others have expressed a dislike for toolbox items such as a speed monitoring sign because it represents a monument to the dangerous speeding.

Centennial engineers are always looking for the most accurate crash data analysis software. The weakness of Intersection Magic could be reason to explore other software to analyze crash data more accurately. This becomes crucial when projects meet minimum NTMP requirements based on safety concerns relating to crashes rather than speeding.

On a broader scale, traffic calming and NTMPs are continuously evolving. Centennial engineers need to keep reviewing the NTMP policies from other cities to keep up to date on the latest practices and ideas for new toolbox items. The combination of the three E's and ongoing evaluation of local and non-local NTMPs will lead to improvements to the Centennial NTMP. 


\subsection{REFERENCES}

1. Ewing, R. Traffic Calming: State of the Practice, ITE/FHWA, Washington, D.C., 1999.

2. State of the Art Report: Residential Traffic Management, U.S. Department of Transportation, Federal Highway Administration, Report No. FHWA/RD-80/092, Washington, D.C., 1980.

3. City of Centennial Website. Our Story, 2015.

4. Womack, M. Bloomberg Philanthropies Expands Innovation Teams Program to 12 New American Cities, Bloomberg Philanthropies, 2014.

5. United States Census Bureau. State \& County Quick Facts, 2015.

6. National Oceanic and Atmospheric Administration (NOAA). United States Department of Commerce. Website. 2015

7. City of Centennial. Neighborhood Traffic Management Program, Centennial, Colorado, 2013.

8. City of Lee's Summit. Neighborhood Traffic Safety Program, Lee's Summit, Missouri, 2008.

9. City of Scottsdale. Neighborhood Traffic Management Policy and Procedure, Scottsdale, Arizona, 2010.

10. City of West Jordan. Neighborhood Traffic Management Program, West Jordan, Utah, 2009. 